Board of Governors of the Federal Reserve System

\author{
International Finance Discussion Papers \\ Number 940
}

August 2008

\title{
Friends or Foes? The Stock Price Impact of Sovereign Wealth Fund Investments and the Price of Keeping Secrets
}

\author{
Jason Kotter \\ Ugur Lel
}

NOTE: International Finance Discussion Papers are preliminary materials circulated to stimulate discussion and critical comment. References in publications to International Finance Discussion Papers (other than an acknowledgement that the writer has had access to unpublished material) should be cleared with the author or authors. Recent IFDPs are available on the Web at www.federalreserve.gov/pubs/ifdp/. This paper can be downloaded without charge from Social Science Research Network electronic library at http://www.ssrn.com/. 


\title{
Friends or Foes? The Stock Price Impact of Sovereign Wealth Fund Investments and the Price of Keeping Secrets
}

\author{
Jason Kotter and Ugur Lel ${ }^{*}$
}

\begin{abstract}
This paper examines the stock price impact of 163 announcements of Sovereign Wealth Fund (SWF) investments. We document an average positive risk-adjusted return of 2.1 percent for target firms during two days surrounding SWF acquisition announcements. The announcement effect is both statistically and economically significant. A multivariate analysis shows that the degree of transparency of SWF activities is an important determinant of the market reaction, and both the SWF and the existing shareholders of the target firm benefit from improved SWF disclosure. In addition, target firms' profitability, growth, and governance do not change significantly in the three-year period following the SWF investment relative to a control sample. These results are robust to a battery of tests. Overall, our findings suggest that SWF investments convey a positive signal to market participants about the target firm, increased SWF transparency is enjoyed by both the SWF and existing shareholders, and SWFs are passive investors.
\end{abstract}

JEL Classification: G14, G15, G34, G38

Keywords: International Finance, Sovereign Wealth Fund, Cross-border Investment, Market Efficiency, Transparency.

* Research assistant and economist, respectively, in the Division of International Finance of the Board of Governors of the Federal Reserve System. We would like to thank Carol Bertaut, Mark Carey, Sally Davies, Darius Miller, and Edwin Truman for their comments. The views in this paper are solely the responsibility of the authors and should not be interpreted as reflecting the views of the Board of Governors of the Federal Reserve System or any other person associated with the Federal Reserve System. 


\section{Friends or Foes? The Stock Price Impact of Sovereign Wealth Fund Acquisitions and the Price of Keeping Secrets}

The size of assets under the control of Sovereign Wealth Funds (SWFs) has grown from $\$ 500$ billion in 1995 to about $\$ 3.3$ trillion in 2007, and is expected to quadruple by 2015 . To put this number in perspective, much publicized hedge funds and private equity funds, both of which are highly leveraged and include some SWF investments, have assets in the order of about $\$ 1.9$ trillion and $\$ 0.8$ trillion, respectively. ${ }^{1}$ Further, fueled by rising oil revenues and trade account surpluses, several countries have recently initiated a SWF while several others are contemplating establishing one. ${ }^{2}$ The size and rapid growth of SWFs suggest that they are an important class of investors and will likely become more important in the future.

The fact that SWFs are foreign government-owned has led to a recent debate on cross-border investments. On one hand, SWFs are viewed as perilous investors with strategic and potentially politically driven plans that may destabilize financial markets. ${ }^{3}$ Target firms technically become partially state-owned, and as such, a major concern is that their investments can lead to inefficient outcomes as a large body of literature suggests for state-owned enterprises (e.g., Dewenter and Malatesta, 2000). Further, foreign governments that own SWFs may tunnel the target firm's assets or transfer its sensitive know-how out of country using their positions as large shareholders of the firm. ${ }^{4}$ The opaqueness surrounding SWFs' activities only intensifies these concerns. ${ }^{5}$ In fact, the lack of transparency of SWFs has prompted several recipient countries including the United States to debate whether and to what degree to regulate SWF cross-border 
investments, and the IMF, OECD, and a group of SWFs to work on best practices principles aimed at improved SWF transparency. ${ }^{6}$

On the other hand, SWFs are regarded as long-term, passive investors who play an important role in deepening financial globalization. Some observers argue that despite being government-owned, SWFs behave like institutional investors such as Berkshire Hathaway with the objective of profit maximization. They also provide sizable crossborder liquidity into the global financial system, which is particularly important for countries with current account deficits such as the United States. In addition, largely devoid of highly leveraged positions and stringent capital requirements, they can help stabilize financial markets in times of elevated uncertainty. ${ }^{7}$

Despite their importance, very little is known empirically about the valuation impact of SWF investments. In this paper, we provide detailed empirical evidence on the wealth effects of SWF investments on shareholders of target firms. Specifically, we examine a) the stock market reaction to announcements of SWF investments in firms, b) the impact of the degree of transparency of SWFs' activities on this market reaction, and c) how the operational performance and corporate governance environment of target firms change following the SWF investment.

Examining the initial stock price impact of 163 announcements of SWF investments in 28 countries, we document a risk-adjusted positive abnormal return of 2.1 percent on two days surrounding the announcement date. The announcement effect is economically and statistically significant. Moreover, the effect is not short-lived, as target firms continue to experience a positive cumulative abnormal return (CAR) on average in the 20-day period following the announcement date. The magnitude of the average CAR 
is similar to announcement effects of investments by hedge funds and institutional investors like CalPERS on stock returns for a comparable event window (e.g., Brav et al, 2008; Del Guercio and Hawkins, 1999), indicating that SWF investments convey a positive signal to market participants about future risk-adjusted returns of target firms.

The multivariate analysis from cross-sectional regressions shows that the transparency of SWFs plays a major role in determining investors' reaction to the acquisition announcement. Using the SWF scoreboard developed by Truman (2008), we document that firms experience higher CARs if the investing SWF is more transparent. For example, controlling for various SWF, firm, and country characteristics, we document that the average CAR is more than 3.5 percent higher in absolute terms for firms targeted by SWFs that are subject to independent audits or make annual reports publicly available. This finding suggests that investors use voluntary SWF disclosure as a signal of the quality of screening and monitoring by SWFs. We also analyze who benefits from increased SWF transparency and find that both the SWFs and existing shareholders of the target gain from voluntarily improved SWF transparency. The benefits that accrue to SWFs from higher disclosure are one third of that enjoyed by shareholders.

Next, we analyze the reasons underlying the positive market reaction to SWF investments. Specifically, we test if the market reaction is due to SWF-related shareholder activism, liquidity effects generated by block purchases of SWFs, a potential transfer of wealth from target firms' creditors to shareholders, or information effects of the stock picking abilities of SWFs. Our results reveal that target firms do not experience any robust and statistically significant change in their profitability, growth, investment, and corporate governance environment in the three year period following the SWF 
investment compared to a control sample of firms matched with respect to the country, industry, and profitability of target firms in the year prior to the SWF investment. These results show that SWFs do not improve firm value in long run, suggesting that shareholder activism is not common among SWFs, which is consistent with the empirical evidence documented for U.S. institutional investors. ${ }^{8}$ These results also imply that SWF investments do not deteriorate firm value.

We also do not find any indication that the positive market reaction is driven by a temporary liquidity effect produced by block purchases by SWFs or that it comes at the expense of target firms' creditors. Other alternative explanations such as the expectation that SWFs may recapitalize the target firm in case of future financial difficulties are not supported by the data. Therefore, by process of elimination, our findings suggest that SWFs are passive shareholders who invest in under-priced securities.

Our results are robust to the inclusion of firm-specific financial and ownership control variables such as firm size, growth opportunities, and the presence of institutional investors; deal characteristics such as the size and type of investment in the target firm; country-specific variables such as investor protection laws, and stock market capitalization of the countries of SWFs and target firms; SWF characteristics such as the type of funding, age, and estimated size; and industry and year controls. We also conduct a series of robustness checks to gauge the sensitivity of our results to alternative benchmarks, estimation procedures, and sub-samples. In all instances we find that our results continue to hold.

Our results contribute to the extensive literature that studies the impact of crossborder M\&A transactions and share purchases by institutional shareholders on target 
firms' stock prices and governance (e.g., Holderness and Sheehan, 1985; Bris and Cabolis, 2008; Brav et al, 2008; Del Guercio and Hawkins, 1999). We provide detailed empirical evidence on the valuation impact of an important class of institutional investors, namely SWFs, which are foreign government-owned, larger than hedge funds and private equity funds, and generally operate in a very opaque environment. Our evidence suggests that SWF investments have a strong positive effect on stock prices around the announcement date and no substantial effect on operational performance and corporate governance outcomes, consistent with the empirical evidence on share purchases of institutional shareholders (e.g., Karpoff, 2001). Our paper is also relevant for the literature on state-owned enterprises, as our findings suggest that limited government ownership of publicly traded firms does not necessarily lead to a deterioration of performance when the target firm is publicly traded and the government is a passive shareholder. ${ }^{9}$

Our paper also helps academics and regulators alike to better understand SWFs' motives by examining how investors perceive SWF investments. Our findings show that market participants react favorably to SWF investments, suggesting that they view SWFs as profit-oriented investors. At the same time, a positive and statistically significant relation between the market reaction and the degree of SWF transparency implies that market participants use voluntary disclosure by SWFs as a signal of SWF type. This evidence is supportive of policies recently initiated by SWFs to voluntarily increase their disclosure standards. ${ }^{10}$

The remainder of the paper proceeds as follows. Section 1 provides the background information on SWFs. Section 2 describes the data. Section 3 presents event 
study results. Section 4 presents the research design, multivariate regression results, and robustness tests. Section 5 investigates possible explanations for the positive market reaction. Section 6 concludes.

\section{Background on Sovereign Wealth Funds}

There is no universally accepted definition of SWFs, although many definitions have been proposed. This paper defines SWFs as government-owned investment vehicles with no explicit liabilities, significant exposure to high risk foreign assets, and a longterm investment horizon. ${ }^{11}$ The main stated objectives of SWFs are to provide intertemporal stabilization, diversification, and risk-return optimization for nations (Kern, 2007). While SWFs invest in a variety of assets, including equity and debt securities, commodities, and property in order to achieve these goals, there is a belief that they are shifting from bonds to equities (Johnson, 2007). The asset allocation of SWFs is estimated to be 35 to 40 percent in fixed income securities, 50 to 55 percent in equity securities of public firms, and 8 to 10 percent in alternative investment products such as private equity securities, hedge funds, and commodities (Fernandez and Eschweiler, 2008).

Table 1 provides some information about the largest SWFs. ${ }^{12}$ Abu Dhabi Investment Authority is the largest SWF, with assets estimated to range from $\$ 250$ billion to $\$ 875$ billion. The next largest SWFs are the Norwegian Government Pension Fund and the Government of Singapore Investment Corporation, controlling about $\$ 375$ billion and $\$ 150$-330 billion, respectively. The primary sources of funding for these largest SWFs are 
oil revenues, foreign exchange reserves, and government savings (Coulibaly, Davies, and Vitanza, 2007).

Table 1 also shows that the Kuwait Investment Authority is the oldest SWF, established in 1953. Since then, there have been two major waves in SWF establishment-during the 1970 s and from 2000 to present. There are now around 40 active or announced SWFs worldwide. The recent increase in the number of countries with SWFs is impressive; about 35 percent of SWFs currently operating were launched in the last five years. Figure 1 displays further evidence of SWF asset growth from their activities in the United States. It shows that holdings of U.S. corporate equity and debt by foreign official institutions, which can be considered as a proxy for SWF investments, has increased substantially since the beginning of 2000 [from $\$ 89$ billion and $\$ 13$ billion in 2000 to $\$ 266$ billion and $\$ 98$ billion as of June 2007 in equity and debt securities, respectively], confirming this trend (Bertaut and Tryon, 2007). ${ }^{13}$ Funding for this rapid growth has been made possible by growing current-account surpluses from increased prices for non-renewable resources (primarily oil, but also copper, diamonds, and phosphate) and accumulation of foreign currency reserves through interventions in FX markets.

This growth in both the number of SWFs and size of assets under their control makes them an important class of investors, larger than hedge funds, but smaller than official reserves as shown in Figure 2. ${ }^{14}$ SWFs are fundamentally different from official foreign reserves, where liquidity and security issues necessitate a short investment horizon and low risk tolerance. ${ }^{15}$ SWFs also differ from other large investors such as 
mutual and pension funds, as the former represent foreign government assets with no specific liabilities to be paid to shareholders.

SWFs are more analogous to hedge funds and private equity funds in the context that they are all active in debt and equity markets; there is a high level of opaqueness in the way they operate; and they are unregulated, albeit SWFs are much more opaque. ${ }^{16}$ However, there are also some major differences between these classes of investors; hedge funds and private equity funds are owned by a group of public or private shareholders and generally engage in highly leveraged transactions, while SWFs are foreign government entities that use little leverage. Thus, while managers of the former group of investors may own a significant stake in their institutions and report to shareholders (which aligns shareholders' and managers' incentives), most SWFs are run by bureaucrats who do not explicitly own any portion of the fund, giving rise to potential agency conflicts.

\section{Data and Descriptive Statistics}

Our sample consists of 163 SWF investment announcements that are hand collected from searching the Factiva database from 1980 to 2008 using key words such as "invest", "stake", and "acquire" combined with the SWF name for those SWFs shown in Table 1 in addition to their well-known, wholly owned subsidiaries. ${ }^{17}$ The announcement date is taken as the earliest press release in English. We collect information on both equity investments (145 announcements) and joint ventures (18 announcements) by SWFs.

This search results in a total of 271 events, of which 63 are investments in firms without publicly traded equity. Of the remaining 208 firms, 13 are investments in initial 
public offerings. The sample is further limited to cases in which returns data on the underlying stock are available 200 days before the announcement date and ending at least 30 days after the announcement date. The final sample consists of 163 investment events in 135 unique firms, with some firms receiving multiple SWF investments through time between 1982 and April, 2008. Returns data for each stock and its corresponding market index are collected from the Datastream International database. This sample is then combined with firm-level data collected from Thompson Financial and Bloomberg, country level data from World Bank and Djankov, La Porta, Lopez-De-Silanes, and Shleifer (2005), and SWF-specific data from various sources including Truman (2008). The sample used in the cross-sectional regression analysis is reduced to 124 observations (106 firms) as a result of this matching, covering announcements between 2000 and April 2008.

Table 2 provides descriptive statistics for our sample firms. In particular, panel A displays the distribution of our sample across the country of target firms. SWFs have invested in firms from 28 countries so far, with India attracting the most SWF investments to date. While Malaysia, Singapore, and the United States closely follow India, some investments in the former two countries are made mostly by the domestic SWFs. Panel B presents a sample distribution based on the investing SWF. Temasek Holdings is the most active SWF in our sample, with a total of 67 investments made in firms between 1982 and 2008. Our results reported throughout the paper are robust to the exclusion of investments made by Temasek Holdings. The second most active SWF is Investment Corporation of Dubai with 22 investments. Most of the announcements are from 2004 onwards, with the pre-2004 period including only 12 percent of the sample. 
The scope of our analysis of SWF investments is limited, as we take advantage of news announcements in examining the valuation impact of SWF investments. Because generally only large investments by SWFs make it to newspaper headlines, it is possible that SWFs behave differently in the case of small transactions. However, we believe our empirical specification is justified on the basis that such investments are the ones that can lead to the most pronounced adverse outcomes for target firms as they involve the transfer of large controlling stakes. Further, SWFs may control other firms via pyramidal and other complex ownership structures. Our analysis of SWF investments includes only direct investments by SWFs and their well-known fully-owned affiliates.

\section{The Market Reaction to Announcements of SWF Investments}

We conduct an event study procedure to measure changes in share value around the announcement of a SWF investment. To measure abnormal returns, we estimate a market model for each firm using local currency daily returns. As a proxy for the market return, we use a market capitalization weighted index for each country from Datastream International. $^{18}$

With the announcement day defined as day 0, OLS market model coefficients are estimated over a 200 day pre-event period, from day -225 to day -26 relative to the announcement date. Coefficients from the pre-announcement model are used to calculate abnormal returns from day -10 to day +20 . Abnormal returns are then averaged across firms to form the average abnormal return. Table 3 presents average abnormal returns for the $(0,+1),(-1,+1)$, and $(-2,+2)$ windows. Figure 3 summarizes the evidence. 
Panel A of Table 3 reports abnormal returns around the announcements of SWF investments for the entire sample of 163 observations during the period between 1982 and 2008. The average cumulative abnormal return is 1.94 percent $(t=4.22), 2.15$ percent $(t=4.17)$, and 2.43 percent $(t=4.07)$ for the windows $(0,+1),(-1,+1)$, and $(-2$, +2 ) around the announcement date. The sign test statistics are also highly significant for all three windows. In dollar terms, the average firm's market value increases by $\$ 327$ million in the first two days of the announcement of SWF investment. ${ }^{19}$ The positive market reaction is consistent with the findings of studies on hedge funds, private equity funds, and other institutional investors. In particular, the magnitude of CAR is very similar to that reported for hedge funds and higher than that reported for private equity funds, CalPERS, and individual investors such as Carl Icahn for a comparable event window (Brav et al, 2008; Klein and Zur, 2008; Wahal, 1996; Holderness and Sheehan, 1985). On the other hand, it is lower than the average CAR associated with announcements of Berkshire Hathaway investments and negotiated block trades of stocks (Martin and Puthenpurackal, 2007; Barclay and Holderness, 1991). Figure 3 shows that most of the price reaction occurs on the day of the announcement and the following date, and the average CAR remains positive ( 0.6 percent) during the month following the announcement date. These results suggest that investors view SWF investments positively. ${ }^{20}$

Other panels of Table 3 present the cumulative abnormal returns for different subsamples. Panel B reports CARs for the subsample of firms that received SWF investments in the form of equity purchases. The average CAR for the $(0,+1)$ window is 2.06 percent $(\mathrm{t}=4.04)$. CARs for other windows are also positive and statistically and 
economically significant. In panel $\mathrm{C}$, we exclude firms that receive additional SWF investments following the first one, and find that the average CAR slightly increases to 2.16 percent for the $(0,+1)$ window and again is highly statistically significant.

In the next panel we report CARs for the sample of firms that make it to the crosssectional regression analysis in the next section. It shows an average CAR of 1.46 percent $(\mathrm{t}=3.14)$ for the $(0,+1)$ window. CARs for other windows are also positive and statistically significant. Panel E shows that the average CAR for cross-border investments, which comprise 90 percent of our sample, is 1.7 percent and highly significant.

Finally, we examine if the market's perception of SWFs as knowledgeable investors has increased over time by splitting the sample to two time periods, 1982 through 2005, and 2006 through April, 2008. Results are reported in the last two panels. Comparing average CARs across panel $\mathrm{F}$ and panel $\mathrm{G}$, we observe that the average market reaction has more than doubled in recent years, from 1.04 percent in the pre-2006 period to 2.56 percent in the post-2005 period for the $(0,+1)$ window. The difference is also statistically significant at 1 percent, suggesting the market participants might have judged previous years' SWF investments to contain valuable information, thus justifying an increased reaction to more recent announcements. ${ }^{21}$ Overall, Table 3 provides strong evidence that SWF investments convey positive information to market participants about the target firm. 


\subsection{The Market Reaction to Announcements of SWF Disinvestments}

We also examine how stock prices change in reaction to announcements of disinvestments by SWFs. The sample is fairly small and consists of 12 firms for which we are able to find an announcement in newspapers. We find that in the $(0,+1)$ window there is a statistically significant and negative stock market reaction when a SWF announces that it is exiting the firm $(-1.43$ percent, $t=-1.87)$. This result is consistent with those in Table 3 for announcements of SWF investments, and further suggests that SWF investments receive a favorable market reaction.

\section{Multivariate Regression Results}

In this section, we investigate what firm, country, and SWF characteristics are associated with the positive market reaction. We are particularly interested if the opaqueness of SWFs influences investors' perception of the value of SWF investments in target firms. To achieve this goal, we estimate the following cross-sectional regression;

$$
\begin{aligned}
\text { CAR }_{i} & =\alpha+\beta \text { SWF transparen cy }+\lambda \text { SWF controls }+\delta \text { Firm controls }+\gamma \text { Deal controls } \\
& +\varphi \text { Country controls }+\psi \text { Year dummies }+\xi \text { Industry dummies }+\varepsilon_{i t}
\end{aligned}
$$

where $C A R$ is the cumulative abnormal return for the $(0,+1)$ window averaged across observations as described in section $3, S W F$ transparency is an index constructed by either Truman (2008) or the SWF Institute to measure the transparency and accountability of SWFs' activities, SWF controls include the size and age of SWFs, firm controls is a set of firm-specific financial and ownership variables, deal controls is a set of variables related to acquisition characteristics, and country controls are the differences in investor protection environment and the ratio of stock market capitalization to GDP 
between the countries of the SWF and target firm. Each regression specification also includes industry controls based on the Fama and French (1997) classification and year controls.

We choose CARs of the $(0,+1)$ window as the dependent variable in our crosssectional regressions because most of the stock market reaction occurs on these two days. However, we repeat all the analysis in this section using CARs of alternative windows ($1,+1)$ and $(-2,+2)$, and find that our results are not sensitive to the choice of event window.

\subsection{Measuring the Degree of Transparency of SWFs' Activities}

Our main interest is in a set of variables related to the transparency and accountability of SWFs' activities. We use two separate indexes. The first index is recently developed by Truman (2008) that rates 34 SWFs based on their disclosure, structure, and investment decision making process. ${ }^{22}$ Specifically, each SWF is given an overall score (Score) based on the cumulative ranking of four major characteristics of SWFs: their transparency and accountability, structure, governance, and behavior. The first sub-index is transparency, which is a set of variables that proxy for the disclosure practices of SWFs and the degree of rigorousness of the accountability and auditing of their activities and performance. Higher values of this index represent increased SWF accountability and transparency. Governance is based on a group of variables that proxy for the existence of investment guidelines and the role of the government and SWF managers in setting and executing them. SWFs with higher values of governance are 
characterized in general as better governed and have more disclosure on their governance environment.

The third sub-index, structure, includes variables that cover the basic structure of the fund such as its organizational ties with the government budget and international reserves. Higher values of this sub-index correspond to clearer guidelines for the structure and scope of SWF activities. Finally, behavior contains a set of policies on how investments are made, such as the speed of adjustment in their portfolios and the use of leverage and derivatives. Higher values of behavior indicate that in general the SWF has more advanced investment and risk management strategies in place.

The second SWF transparency index, transparent, is developed at the SWF Institute, which rates SWFs on various aspects of their disclosure policies. ${ }^{23} \mathrm{~A}$ detailed description of each transparency index and the related individual components is reported in the Appendix. In our analysis, we not only report results for the overall index and the four major sub-indexes, but also results on the impact of each individual component of these indexes on the market reaction to SWF investments when available.

\subsection{Control Variables}

We follow previous research in defining other variables in equation (1). Specifically, we use six variables to control for firm-specific factors. The first variable is $\log$ assets, measured as the natural logarithm of the book value of total assets in millions of U.S. dollars. It is a proxy for the degree of informational asymmetry, as smaller firms tend to be more opaque. Our second variable is leverage, defined as long-term debt plus short-term debt divided by assets. It is used to proxy for the likelihood of financial 
distress for target firms. Our proxy for firm growth is sales growth measured over the previous year (sales growth), and the proxy for profitability is net income divided by assets $(R O A)$. Our fifth variable is the percentage of shares held by institutional shareholders of the target company (institutional holdings), which controls for the ownership structure of target firms. Our final firm-specific variable is the ratio of intangible assets to assets (intangible assets ratio). This variable is used as a proxy for the intensity of know-how and uniqueness of the target firm. It is also used to proxy for the degree of bondholder-related agency costs, as tangible assets present lower risk to bondholders (Rajan and Zingales, 1995). Missing values of the last two variables are set to zero. ${ }^{24}$

We use two variables to control for country-specific factors, both of which are defined as in Bris and Cabolis (2008). The first variable measures the difference in investor protection regimes between the countries of the SWF and target firm. Our proxy for the strength of investor protection is whether the legal origin of the respective country is common law or not (Djankov et al, 2005; World Bank's Cost of Doing Business Survey, 2006). The second measure is both country and time-varying and is related to the difference in the degree of financial market development of the country of the SWF and target firm, namely the difference in the ratio of stock market capitalization to GDP between the countries of the SWF and target firm.

We also use two SWF-related factors as control variables. SWF age is the number of years since the SWF's inception, and SWF size is the dollar value of assets under the control of the SWF, measured in billion dollars. If SWF size is only available as a range, the midpoint is used. We use the natural logarithm of these variables. 
Three variables are used to control for deal-specific factors. Stake is the percentage of the target firm's equity purchased by the SWF ${ }^{25}$ It is used to proxy for the degree of control acquired by the SWF in the target firm. Domestic is a dummy variable that equals one if the SWF investment is within the country of the SWF; the degree of informational asymmetry between investors and the SWF is likely lower for such investments. Equity is an indicator variable that takes on the value of one for investments in equity securities, and zero for joint-venture investments. It is used to control for a potential impact of the type of investment on the market reaction.

In the regression analysis we winsorize the continuous variables at the one percent level. Our regressions also correct standard errors for possible serial correlation and heteroscedasticity by clustering at the country level using the Rogers method. It is also important to note that throughout our analysis, we include industry and year fixed-effects, which ensure our variables of interest are not picking up across-industry and trend effects.

Table 4 provides summary statistics for each of the above variables used in the cross-sectional analysis. The median target firm size is $\$ 4.8$ billion but the distribution of asset size is highly skewed due to the relatively large size of global banks like UBS. The median equity stake acquired by SWFs is 5 percent, with only about 5 percent of SWF investments exceeding the 50 percent threshold. Thus, SWFs do not appear to be interested in taking control of the target firm. Pair-wise correlations between the firm, country, SWF, and deal specific variables used in the regression analysis show that SWF characteristics are positively correlated with the CAR, although these correlations are not statistically significant (untabulated). 


\subsection{Results}

Table 5 reports regression results using the specification in equation (1). The first column shows that controlling for various firm, country, SWF, and deal characteristics as well as industry and year effects, target firms experience higher abnormal returns if the investing SWF ranks higher in terms of its overall disclosure standards. Specifically, Score has a positive and statistically significant coefficient, $0.003(\mathrm{t}=2.291)$. In economic terms, firms targeted by SWFs with the index value of 15 (e.g., Temasek Holdings from Singapore) have 3.6 percent higher abnormal returns compared to those SWFs with a rating of 3 (e.g., Abu Dhabi Investment Authority and Corporation from the U.A.E.).

In columns (2) through (5), we replace score with its four major components one at a time: transparency, structure, governance, and behavior. In particular, the second column shows that the coefficient on transparency is 0.006 and statistically significant $(\mathrm{t}$ $=3.241)$. In terms of economic significance, a one standard deviation increase in transparency from its mean level of 5.9 to 9.1 increases target firm CARs by 1.9 percent. The next three columns report results on the other three components of score. The coefficient on governance, reported in column (3), is also positive and statistically significant $(0.01$ and $\mathrm{t}=1.886)$. The coefficients on structure and behavior are statistically insignificant, suggesting they do not have any effect on the magnitude of the stock price impact.

In the sixth column we include all four components of score from Truman (2008) in the same regression specification. It shows that the main driver of the impact of score on the market reaction to SWF acquisitions is transparency, as the coefficient on transparency is 0.011 and statistically significant $(\mathrm{t}=3.11)$. The economic significance 
of transparency increases and the previously reported statistically significant effect of governance on the market reaction disappears when we consider the four components concurrently in the same model. ${ }^{26}$

Finally, we examine the impact of the SWF disclosure policies on the market reaction using the transparency index developed at the SWF Institute. The last column displays a positive and statistically significant coefficient on this index. Specifically, the coefficient on transparent is $0.009(\mathrm{t}=2.39)$, which is consistent with the results from the Truman (2008) transparency index.

When we run the regression specification in equation (1) separately for observations in which the announcement follows vs. precedes the actual SWF investment in the target firm, we find that in both cases transparency is positive and statistically significant. Specifically, the coefficient on transparency is $0.0033(t=1.75)$ when the announcement follows the actual SWF investment in the target firm and $0.0109(\mathrm{t}=2.81)$ when it precedes the actual investment. This finding suggests that improved transparency benefits both the SWFs and existing shareholders of the target firm, although the benefits that accrue to SWFs from higher disclosure is only one third of that enjoyed by shareholders (the difference is statistically significant at the 10 percent level).

Table 5 also reports that among firm, deal, and country characteristics, institutional ownership in the firm and the difference in the degree of financial market development ( $\triangle$ Stock Market Cap/GDP) are positively related to abnormal returns. Neither the percentage of target firm's equity acquired by the SWF (stake) nor the differences in investor protection laws ( $\triangle$ Common Law) influence CARs. ${ }^{27}$ 
We next investigate the impact of individual components of score on the stock price impact of SWF investments to better understand what aspects of disclosure are related to excess returns, and report the results in Table 6. Each row represents a separate regression in which an individual component of the Truman (2008) scoreboard is included in addition to all the firm, deal, country, and other SWF characteristics as well as industry and year fixed effects reported in Table 5. We only report the coefficient estimate on the individual component of the SWF index for brevity. ${ }^{28}$ Table 6 shows that whether the SWF provides an annual report (annual report) and whether it is subject to an audit which is independent (independent audit) or made publicly available (published audit) are highly valued by investors. In such cases, the target firms' average CAR increases between 5.8 percent and 3.3 percent in absolute terms, and the associated coefficients are highly statistically significant. Similar results are obtained for various aspects of disclosure, such as if the SWF discloses information about where it invests geographically and how much it earns from its investments. The most economically significant impact comes from whether the SWF provides information on its specific or major investments (specific), which has a coefficient of $0.073(\mathrm{t}=3.419) .{ }^{29}$

The characteristics of SWFs related to governance also influence how investors view SWF investments in firms. In terms of their governance, whether the role of the manager in executing investment strategy is clearly established and the SWF has publicly available guidelines for corporate responsibility positively affects the stock price impact. We also find that investors react more positively to the investments of SWFs if their managers are allowed to make decisions on specific investments. 
On the other hand, there is only weak evidence that the structure of SWFs matter in explaining the market reaction to SWF investments. Table 6 shows that only three components of structure are important: whether the SWF's objective and overall investment strategy are clearly communicated, and if the source of funding to SWFs is disclosed. The characteristics of SWFs related to their behavior do not appear to have any substantial impact on the stock market reaction. Overall, these results are consistent with the idea that investments by SWFs with public commitment to profit maximization have more impact on stock returns.

\subsection{Robustness Tests}

Next, we examine the sensitivity of our results on the degree of transparency of SWFs' activities to alternative estimation procedures, samples, and variable definitions. Our first set of robustness tests are based on the entire sample, and are reported in panel A of Table 7. Again, each row represents a separate regression in which the reported variable is added to all the firm, deal, country, and other SWF characteristics reported in Table 5. We only report the coefficient estimate on the key variable of interest for brevity.

Specifically, the first row replicates the model reported earlier in column (6) of Table 5 using random country effects based on the country of the target firm. We first conduct a Hausman specification test and find that the random country effects specification is appropriate. Results from this estimation shows that transparency has a positive and statistically significant coefficient $(0.006$ and $t=2.222)$, suggesting that unobserved country effects do not affect our results. 
An index based on a summation of individual components may create an artificial effect when none exists. Further, individual components of the Truman indexes are highly correlated with each other. Thus, we use the principal component analysis to obtain the common factor across all individual components of score and transparency. Accordingly, we replace Truman's (2008) overall score and transparency indexes with their common factors extracted from a principal component analysis. The second and third rows of panel A show that our results remain unchanged when we take into account potential problems in the construction of SWF indexes.

The next two rows report results on an indirect measure of transparency, the proportion of directors from private industry sitting on the SWF's board, hand-collected from SWFs' official websites. Private directors are less likely to conceal information because of their concern about personal reputation. Further, they are likely in a better position to tolerate pressure from government officials to hide information, as they already have career opportunities outside the government. Row (4) reports results for a dummy variable indicating the presence of such directors on the SWF's board of directors, and row (5) reports results on the percentage of private directors in the SWF's board. In both cases, the coefficient on the private director variables are positive and statistically significant $(0.031$ and $t=3.782$, and 0.091 and $t=3.073)$.

In row (6) we use the lagged values of firm-specific financial and ownership variables to measure the sensitivity of our results to potential endogeneity, and find that our result on transparency is robust to this specification. In the final two rows, we use an alternative CAR measure, namely the $(-1,+1)$ window and an alternative measure of investor protection laws, the disclosure standards index obtained from the 2006 edition of 
World Bank's Cost of Doing Business Survey. In both cases, we continue to find our result on transparency is robust.

Our next set of robustness tests are based on various subsamples, and are reported in panel B of Table 7. In particular, the first row reports a coefficient estimate of 0.005 (t $=2.632)$ on transparency after excluding 8 contaminated events such as the dissemination of earnings reports during the week surrounding the announcement. In the following row we replicate the regression specification reported in column (6) of Table 5 after excluding investments by Temasek Holdings, as this SWF has the greatest number of announcements in our sample. In rows (3)-(5), we exclude non-equity SWF investments, domestic SWF investments, and firms with multiple SWF investments, respectively. In all instances we continue to find our results are robust. The last row shows that the coefficient on transparency remains positive and statistically significant when we exclude banks. ${ }^{30}$

We also test if our results are driven by acquisitions clustered within a particular year by replicating regressions reported in Table 5 with a correction of standard errors for both year and country clustering and find that the coefficient on transparency is still positive and statistically significant. In addition, we run regressions in which we include more deal-specific controls such as if the SWF purchased shares at a premium or a discount, if the acquisition of shares was on the open market or through private negotiations, and if the actual purchase took place before or after the SWF investment was announced to the public. Our results regarding SWF transparency are robust to the inclusion of such additional variables in the specification (untabulated). 
Finally, we check if restrictions on foreign entry play any role in the stock price impact of SWF investments. Using data from the S\&P's Global Stock Markets Factbook, we create a variable with respect to the severity of legal barriers to capital flows in their respective countries as in Miller (1999). Our results show that restrictions on foreign entry do not appear to influence the stock market reaction (untabulated).

Overall, Table 7 shows that previously reported results on the degree of transparency of SWFs' activities remain unchanged. The stock price impact of SWF investments is higher if there is more disclosure about the activities of SWFs.

\section{Possible Explanations for the Positive Market Reaction}

In this section, we evaluate alternative explanations for the positive stock price impact of SWF investments. We have three main hypotheses: liquidity effects generated by block purchases of SWFs, SWF-related shareholder activism, and information effects resulting from stock picking abilities of SWFs. Our results are consistent with the last hypothesis, which suggest that SWFs are passive shareholders who invest in under-priced securities.

\subsection{Is the positive market reaction due to liquidity effects?}

Block purchases of a firm's shares can increase stock prices due to buying pressure if the purchase does not involve the issuance of new shares by the target firm. However, such effects should be temporary and the stock price should go back to its prepurchase levels without much delay following the purchase. We examine if the positive stock price impact of SWF investments is due to a temporary liquidity effect in two ways. 
First, we analyze whether the positive stock price impact of SWF investments disappears following the announcement date. Figure 3 shows that the price impact continues to remain positive 20 days following the announcement. Second, we investigate if there is a differential price impact to SWF investments between purchases that involve new share issuance versus existing shares. We construct a dummy variable using information reported in announcements about whether the equity purchase involves new shares issued by target firms. ${ }^{31}$ When we include this new variable in our equation (1), we do not find any statistical significance on its coefficient $(-0.006$ and $t=-0.33) .^{32}$ These findings suggest that our results are not driven by a temporary liquidity effect of SWF purchases on stock prices.

\subsection{Is the positive market reaction due to SWF activism?}

One can observe a positive stock price impact upon the announcement of a SWF investment if managers of target firms do not take actions to fully maximize shareholder value, and investors expect SWFs to actively monitor managers as large shareholders to enhance firm value. The empirical evidence on institutional shareholders such as pension funds and mutual funds suggest that such investors play only a small role in shaping the corporate governance environment of target firms (e.g., Karpoff, 2001). On the other hand, several recent papers find strong evidence in support of hedge fund activism in U.S. and U.K. firms (e.g., Brav et al, 2008; Klein and Zur, 2008). Although SWFs are government-owned, we are not aware of any legal rules restraining SWFs from shareholder activism. However, they may be subject to considerable political constraints both at home and in the host country. 
In order to test this hypothesis, we undertake two approaches. First, we examine the impact of several variables that proxy for the severity of managerial agency conflicts on CARs, and second, we analyze changes in firm performance and governance structure in the years following the SWF investment.

\subsubsection{Evidence from multivariate analysis}

We first examine the coefficient estimate on stake, SWF equity ownership in the target firm. Higher SWF share ownership is likely to increase the voting power and reduce the relative monitoring costs for SWFs, which should result in a higher stock price impact if SWFs are active shareholders. Table 5 reports a positive but statistically insignificant coefficient on stake, suggesting that SWF activism is not observed in our sample. We also examine if target firms with more free cash experience higher abnormal returns, as such firms may be especially prone to managerial agency conflicts (Jensen, 1986). Our results show that neither variable has a statistically significant impact on

CARs. ${ }^{33}$ These results suggest that shareholder activism is not common among SWFs.

\subsubsection{A long-run analysis of operational performance and corporate governance}

If SWFs are active shareholders, one can expect them to trigger changes in the performance and governance of target firms. To test this hypothesis, we carry out a longrun analysis of operational performance and governance of target firms following the SWF investment, and use a methodology similar to Karpoff et al (1996).

In particular, we construct a control sample of firms by matching our sample with the Worldscope database with respect to the country, industry, and profitability of the 
sample firms in the year prior to the SWF investment following Barber and Lyon (1996). The industry classification is the 2-digit SIC code obtained from WorldScope, and we require no more than 20 percent difference in profitability between the target and matched firm. Then, we compare four measures of firm performance and one measure of corporate governance between the sample and control firms over two periods: $t-1$ to $t+1$ and $t-1$ to $t+3$, where $t$ is defined as the year of SWF investment in the sample firm. The number of matched pairs decreases substantially when we extend the event window to $t+3$ years. Our measures of operational performance are operating profits to assets, operating profits to sales, return on assets, and sales growth as in Karpoff et al (1996). The proxy for investment policies is capital expenditures to sales, and the proxy for the strength of corporate governance is the sensitivity of CEO turnover to firm performance. $^{34}$

Results from these comparisons are reported in Table 8. Panel A displays results for the $t-1$ to $t+1$ window and panel B displays results for the $t-1$ to $t+3$ window. Both panels show that target firms do not experience any statistically significant change in their profitability, growth, investment, and corporate governance environment following a SWF investment compared to a matched sample of control firms. The difference in operating performance between target firms and control firms is never statistically significant, although there appears to be a deterioration of target firm performance over time. The only statistically significant comparisons are for CEO turnover and capital expenditures.

Specifically, panel A reports that both target and control firms experience a significant drop in CEO turnover within a year of the SWF investment, but the difference 
in turnover between the two sets of firms is not significant. The CEO turnover conditional on firm performance is, however, different between target and control firms and is statistically significant $(\mathrm{t}=-2.09)$. This result shows that firms with better performance (firms with an operating income/assets ratio $>$ sample median) are less likely to be replaced in target firms compared to control firms, suggesting SWFs improve the corporate governance environment of target firms. However, we do not find a symmetric result for firms with poor performance or for the longer event window of $t-1$ to $\mathrm{t}+3 .^{35}$ Panel $\mathrm{B}$ shows an average capital expenditures to sales ratio of 3.6 percent for target firms and -7.75 percent for matched firms, and the difference in both mean and medians is statistically significant at the 5 percent level. This result suggests that SWF investments are associated with increased investment. However, caution is warranted in interpreting these results given that the sample size for this analysis is based on about 15 pairs of firms and we do not find any such result for the alternative event window. Thus, we view results displayed in Table 8 as at best weak evidence of an impact of SWFs on corporate policies and do not highlight them. These results are consistent with the empirical evidence documented for institutional investors in the United States (e.g., Karpoff, 2001; Gillian and Starks, 2007).

Overall, while we cannot rule out the possibility that our proxy variables to test for shareholder activism are noisy, and therefore SWFs are active shareholders, a more plausible interpretation is that shareholder activism is not common among SWFs.

\subsection{Is the positive market reaction due to the information impact of stock picking?}


The final hypothesis is that the positive stock price impact results from investors' belief that SWFs are good at identifying undervalued stocks relative to market participants. In contrast to the previous three hypotheses, this hypothesis does not have any additional conclusive and clear predictions. One indirect way to test this hypothesis is to investigate the stock price impact for firms that had subsequent SWF investments. If the positive abnormal returns are attributable to the information effect of stock picking, we should not observe a significant market reaction to SWF investments subsequent to the first one. We find that the average CAR is positive but insignificant for such firms $(0.003, \mathrm{t}=0.39)$, consistent with the stock picking story.

As we do not find any support for the previous three hypotheses, and obtain some partial evidence in support of this hypothesis, we conclude by process of elimination that SWF investments generate an information effect due to SWFs' stock picking abilities. ${ }^{36}$

\section{Conclusion}

SWFs are larger and in general more opaque than hedge funds and private equity funds. They manage assets in the order of about $\$ 3$ trillion, and their size is expected to quadruple by 2015. The fact that SWFs represent foreign government ownership raises several concerns in recipient countries. First, plenty of empirical evidence points to inefficiencies associated with government ownership (e.g., Dewenter and Malatesta, 2000). Thus, a concern is that SWFs may reduce economic efficiency in host countries by reducing the efficiency of target firms. Second, political motivations of foreign governments may infect the operations of target firms, which is a particularly important concern for investments in strategic sectors such as banks and energy firms. These issues are intensified by a lack of transparency about SWFs' activities, and have prompted 
widespread debates on whether and to what degree to regulate SWFs' cross-border investments.

Despite their importance, very little is known empirically about the valuation impact of SWF investments. In this paper we analyze the wealth effects of SWF investments in target firms. Examining a total of 163 announcements of SWF investments in 28 countries, we document an initial risk-adjusted stock market reaction of a positive and highly statistically significant 2.1 percent on two days surrounding the announcement date. We uncover that target firms experience higher CARs if the investing SWF is more transparent. These findings suggest that market participants not only perceive SWF investments positively, but also take into account how transparent SWFs are in evaluating their investment decisions. Further tests reveal that SWFs appear to be passive shareholders who invest in under-priced securities. These results contribute to the strands of literature on cross-border M\&As, investments by institutional shareholders, and privatization. Our results also have important implications for the policy debate about SWF transparency. By documenting that investors reward SWF transparency, we provide evidence in support of policies recently initiated by SWFs aimed at improved transparency. 


\section{References}

Aizenman, J. and R. Glick, 2007, Sovereign Wealth Funds: Stumbling Blocks or

Stepping Stones to Financial Globalization?, FRBSF Economic Letter, No 2007-38.

Banerjee, A., 1997, A theory of misgovernance, Quarterly Journal of Economics 112, 1289-1332.

Barber, B. and J.D. Lyon, 1996, Detecting Abnormal Operating Performance: The Empirical Power and Specification of Test Statistics, Journal of Financial Economics 41, 359- 399.

Barclay, M., and C. Holderness, 1991, Negotiated Block Trades and Corporate Control, Journal of Finance 46, 861-878.

Bertaut, C. and R. Tryon, 2007, Monthly Estimates of U.S. Cross-border Securities Positions, International Finance discussion papers 910, Federal Reserve Board.

Black, B., 1990, Shareholder passivity reexamined, Michigan Law Review 89, 520-608.

Blundell-Wignall, A., Y. Hu, and J. Yermo, 2008, Sovereign Wealth and Pension Fund Issues, OECD Working Papers on Insurance and Private Pensions, No 14.

Brav, A., W. Jiang, F. Partnoy, and R. Thomas, 2008, Hedge Fund Activism, Corporate Governance, and Firm Performance, Journal of Finance, forthcoming.

Bris, A. and C. Cabolis, 2008, The Value of Investor Protection: Firm Evidence from Cross-Border Mergers, Review of Financial Studies 21, 605-648.

Butt, S., A. Shivdasani, C. Stendevad, and A. Wyman, 2008, Sovereign wealth funds: a growing global force in corporate finance, Journal of Applied Corporate Finance 20, 7383.

Coulibaly, B., S. Davies, and J. Vitanza, 2007, Sovereign Wealth Funds, Unpublished document, Board of Governors of the Federal Reserve System, Washington DC.

Del Guercio, D., and J. Hawkins, 1999, The Motivation and Impact of Pension Fund Activism, Journal of Financial Economics 52, 293- 340.

Dewenter, K., and P.H. Malatesta, 2000, State-owned and Privately-owned Firms: An Empirical Analysis of Profitability, Leverage, and Labour Intensity, American Economic Review 91, 320-334.

Djankov, S., R. La Porta, F. Lopez-de-Silanes, and A. Shleifer, 2005, The Law and Economics of Self-dealing, Journal of Financial Economics, forthcoming.

Fama, E. F. and K. R. French, 1997, Industry costs of equity, Journal of Financial Economics 43, 153-193. 
Fernandez, D.G., Eschweiler, B, 2008, Sovereign Wealth Funds: A Bottom-up Primer, JP Morgan Research, 22 May 2008.

Gillan, S., and L. Starks, 2007, The evolution of shareholder activism in the United States, Journal of Applied Corporate Finance 19, 55-73.

Gupta, N., 2005, Partial privatization and firm performance, Journal of Finance 60, 9871015.

Hermalin, B. and M. Weisbach, 2003, Boards of Directors as an Endogenously Determined Institution: A Survey of the Economic Literature, Federal Reserve Bank of New York Economic Policy Review 9, 7-26.

Holderness, C., and D. Sheehan, 1985, Raiders or Saviors? The Evidence on Six Controversial Investors, Journal of Financial Economics 14, 555-579.

IMF publication, 2008a, International working group of sovereign wealth funds is established to facilitate work on voluntary principles, May 1, 2008.

IMF publication, 2008b, Sovereign Wealth Funds-A Work Agenda, February 29, 2008, available at http://www.imf.org/external/np/pp/eng/2008/022908.pdf.

International working group of sovereign wealth funds press release, July 2008, International working group of sovereign wealth funds meets in Singapore; continues to make progress on drafting set of principles and practices, Press Release No. 08/03.

Jen, S., 2007, How Big Could Sovereign Wealth Funds Be by 2015?, Morgan Stanley Global Research, May 04, 2007, available at http://www.morganstanley.com.

Jensen, M.C., 1986, Agency Costs of Free Cash Flow, Corporate Finance, and Takeovers, American Economic Review, 323-329.

Johnson, Simon, 2007, The Rise of Sovereign Wealth Funds, Finance and Development, 44-3.

Karpoff, J., 2001, The Impact of Shareholder Activism on Target Companies: A Survey of Empirical Findings, Working paper, University of Washington.

Karpoff, J., P. Malatesta, and R. Walkling, 1996, Corporate Governance and Shareholder Initiatives: Empirical Evidence, Journal of Financial Economics 42, 365-295.

Kern, S., 2007, Sovereign Wealth Funds- State Investments on the Rise, Current Issues, Deutsche Bank Research, September 10, 2007.

Klein, A., and E. Zur, 2008, Entrepreneurial Shareholder Activism: Hedge Funds and Other Private Investors, Journal of Finance, forthcoming. 
Laffont, J., and J. Tirole, 1993, A theory of incentives in procurement and regulation, MIT Press, Cambridge, MA.

Lee, G.Y., 2006, Keynote address at the GIC $25^{\text {th }}$ anniversary dinner, July 11,2006 , available at http://www.gic.com.sg/newsroom_speeches_110706a.htm.

Martin, G., and J. Puthenpurackal, 2007, Imitation is the Sincerest Form of Flattery: Warren Buffett and Berkshire Hathaway, University of Nevada working paper.

Maslakovic, M., 2008, Sovereign Wealth Funds 2008, International Financial Services London, available at http://www.ifsl.org.uk.

Masulis, R., C. Wang, and F. Xie, 2007, Corporate Governance and Acquirer Returns, Journal of Finance 62, 1851-1889.

Miller, Darius, 1999, The Market Reaction to International Cross-listings: Evidence from Depositary Receipts, Journal of Financial Economics 51, 103-123.

OECD publication, 2007, International Investment of Sovereign Wealth Funds: Are New Rules Needed? OECD Investment Newsletter, October 2007, Issue 5.

OECD publication, 2008. Sovereign wealth funds and recipient country policies. OECD Investment Committee Report, April 4, 2008.

Perotti, Enrico, 1995, Credible privatization, American Economic Review 85, 847-859.

Rajan, R., Zingales, L., 1995, What Do We Know About Capital Structure? Some Evidence from International Data, Journal of Finance 50, 1421-1460.

Rogers, W., 1993, Regression Standard Errors in Clustered Samples, Stata Technical Bulletin 13:19-23.

Standard and Poor's Corporation, 2000-2007, Global Stock Markets Factbook, Standard \& Poor's, New York, NY.

Truman, E., 2008, A Blueprint for Sovereign Wealth Fund Best Practices, Peterson Institute for International Economics, Policy Brief series No PB08-3, Washington DC.

U.S. Department of the Treasury publication, 2007, Semiannual Report on International Economic and Exchange Rate Policies, Appendix II: Sovereign Wealth Funds, December 2007.

Volpin, P., 2002, Governance with Poor Investor Protection: Evidence from Top Executive Turnover in Italy, Journal of Financial Economics 64:1, 61-90.

Wahal, S., 1996, Pension Fund Activism and Firm Performance, Journal of Financial and Quantitative Analysis 31:1, 1-23. 
World Bank, Cost of Doing Business Survey 2007, available for download at http://www.doingbusiness.org/Downloads/ 


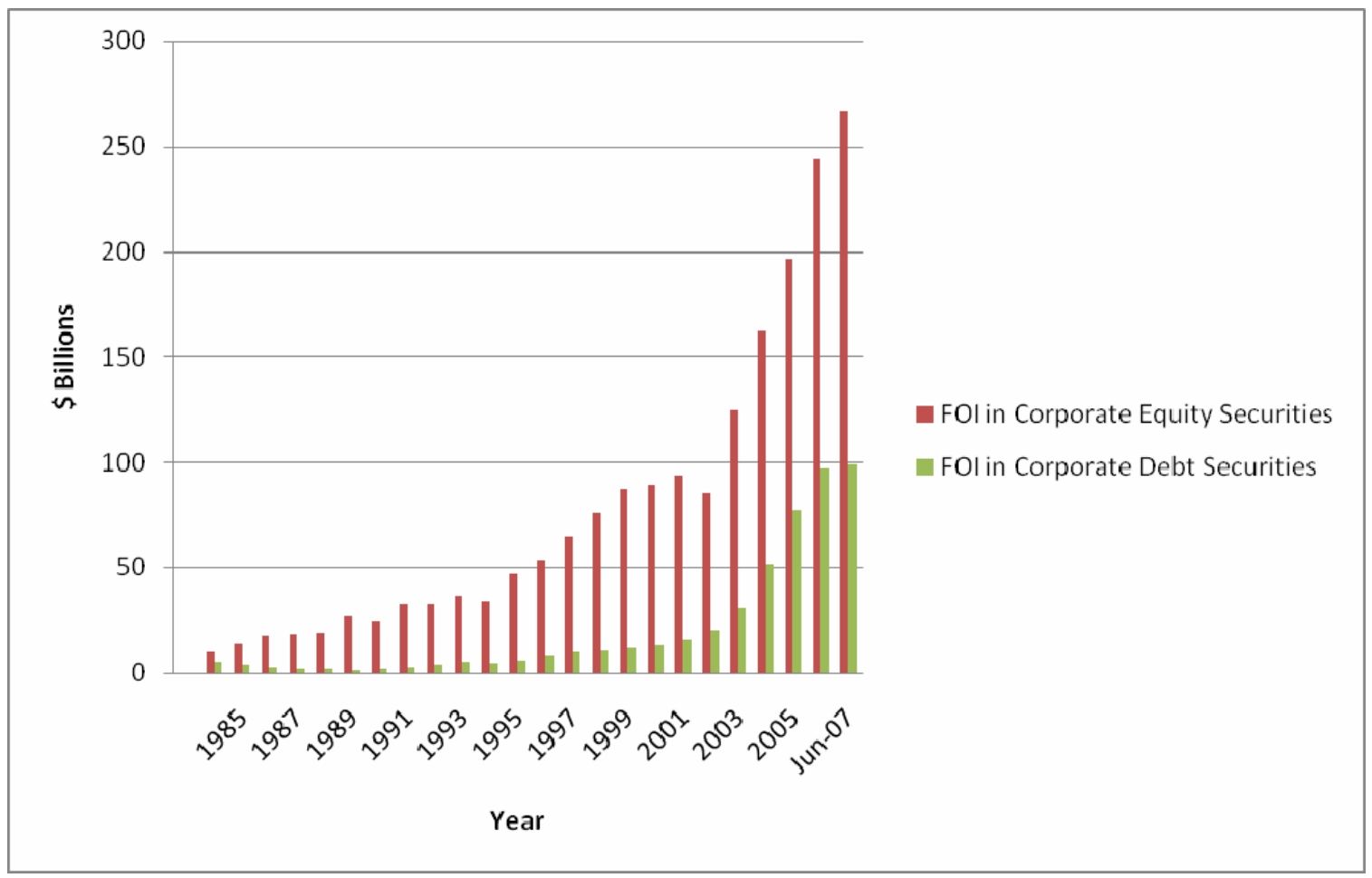

Figure 1. This figure plots time series of annual estimates of holdings of U.S. corporate equity and debt securities by foreign official institutions (FOI) from 1984 through June 2007. Source: Bertaut and Tryon (2007). 


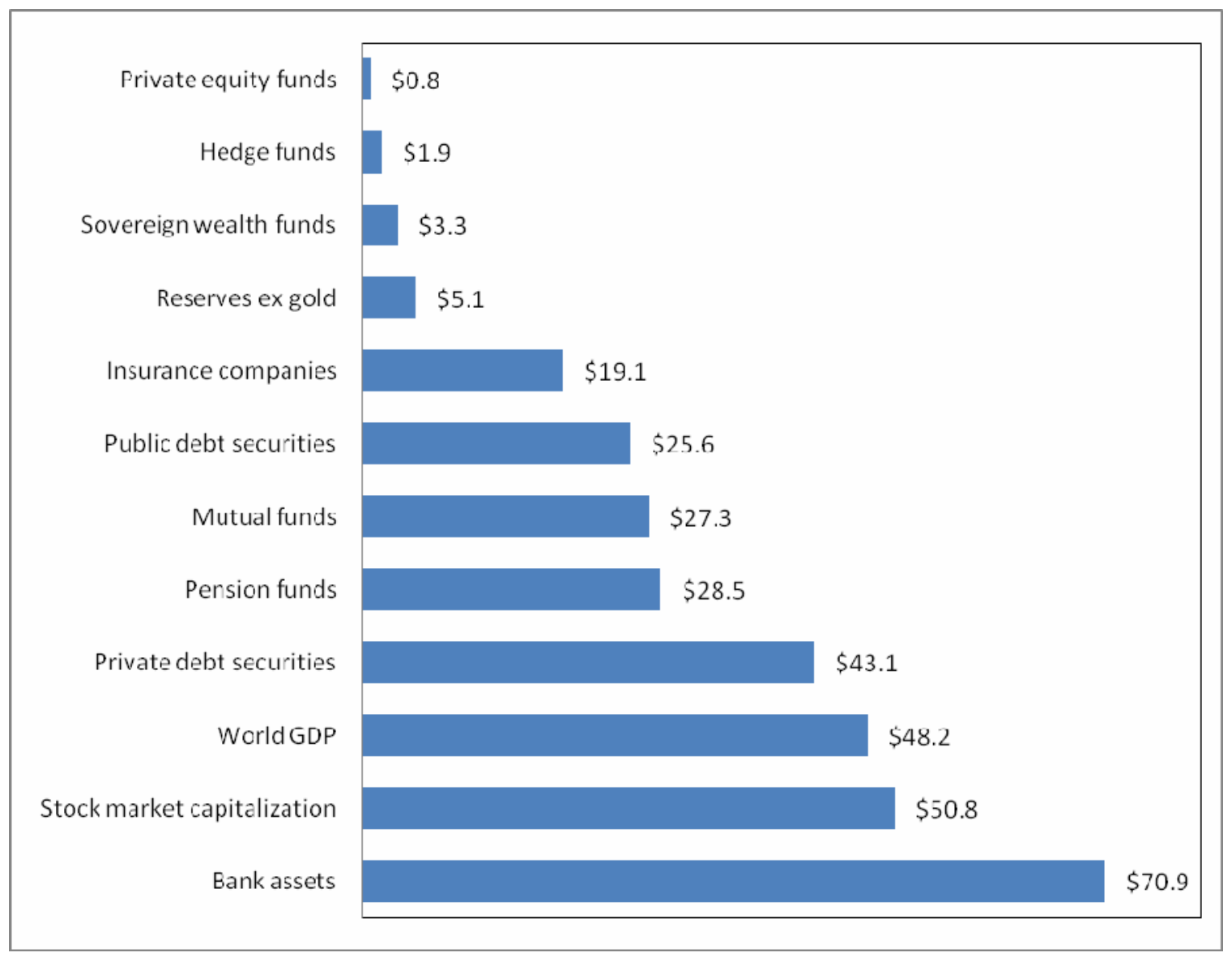

Figure 2. This figure provides a comparison of the size of SWFs to other large investor classes and major financial development indicators. Reported assets are measured in $\$$ trillions. Source: Maslakovic (2008) and various IMF publications. 


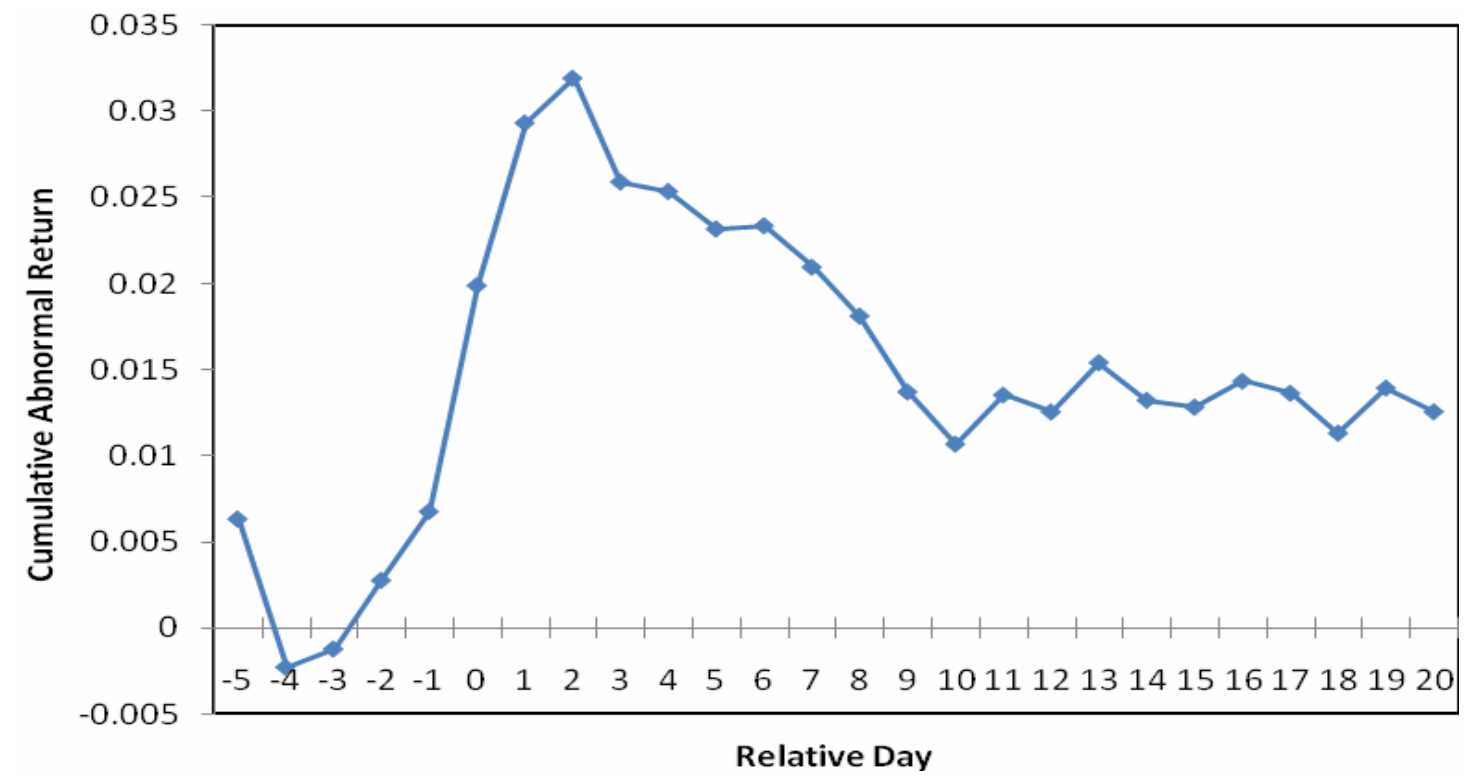

Figure 3. This figure plots cumulative abnormal returns from day -5 before to day +20 after the announcement of an investment by a SWF. The daily abnormal returns are market model adjusted for each firm, averaged across firms, and then cumulated. The sample is for 163 investments in 135 firms. 


\section{Table 1. The Largest 20 Sovereign Wealth Funds}

This table presents the country, source of funds, year of establishment, and estimated assets of the largest 20 SWFs. In cases which the actual value of assets is unknown, the low and high estimates are reported. Sources: Official websites, Truman (2008), the Economist, several IMF publications.

\begin{tabular}{|c|c|c|c|c|}
\hline SWF Name & Country & Fund Source & $\begin{array}{l}\text { Year } \\
\text { Created }\end{array}$ & $\begin{array}{l}\text { Estimated } \\
\text { Total } \\
\text { Assets } \\
\text { (\$ billion) }\end{array}$ \\
\hline Abu Dhabi Investment Authority & United Arab Emirates & Oil & 1977 & $250-875$ \\
\hline Government Pension Fund - Global & Norway & Oil & 1990 & 375 \\
\hline $\begin{array}{l}\text { Government of Singapore Investment } \\
\text { Corporation }\end{array}$ & Singapore & Non-Commodity & 1981 & $150-330$ \\
\hline Kuwait Investment Authority & Kuwait & Oil & 1953 & 213 \\
\hline China Investment Corporation & China & Non-Commodity & 2007 & 200 \\
\hline Temasek Holdings & Singapore & Non-Commodity & 1974 & 111 \\
\hline Investment Corporation of Dubai & United Arab Emirates & Oil & 2006 & 82 \\
\hline Qatar Investment Authority & Qatar & Oil & 2005 & $40-70$ \\
\hline Libyan Investment Authority & Libya & Oil & 1981 & 50 \\
\hline Revenue Regulation Fund & Algeria & Oil & 2000 & 47 \\
\hline Alaska Permanent Fund & USA (Alaska) & Oil & 1976 & 39 \\
\hline National Welfare Fund & Russia & Oil & 2008 & 33 \\
\hline Brunei Investment Agency & Brunei & Oil & 1983 & $30-35$ \\
\hline Korea Investment Corporation & South Korea & Non-Commodity & 2005 & 20 \\
\hline Khazanah Nasional Berhad & Malaysia & Non-Commodity & 1993 & 20 \\
\hline National Fund & Kazakhstan & Oil & 2000 & 18 \\
\hline Social and Economic Stabilization Fund & Chile & Copper & 2006 & 15 \\
\hline Alberta Heritage Savings Trust Fund & Canada & Oil & 1976 & 14 \\
\hline Fonden (National Development Fund) & Venezuela & Oil & 2005 & $2-18$ \\
\hline Mubadala Development Company & United Arab Emirates & Oil & 2002 & 10 \\
\hline
\end{tabular}




\section{Table 2. Descriptive Statistics}

This table presents the distribution of the announcements of SWF investments by the country membership of target firms and by acquirer SWFs. Panel A describes the number of SWF investments across the country of target firms. Panel B displays the distribution of the sample by the identity of the acquiring SWF.

Panel A. Country of Target Firms

\begin{tabular}{|c|c|c|}
\hline Country & $\begin{array}{c}\text { Number of Investments } \\
\text { (All firms) }\end{array}$ & $\begin{array}{c}\text { Number of Investments } \\
\text { (Regression sample) }\end{array}$ \\
\hline Australia & 9 & 9 \\
\hline Austria & 1 & - \\
\hline Canada & 4 & 2 \\
\hline China & 10 & 10 \\
\hline Cyprus & 2 & - \\
\hline France & 5 & 3 \\
\hline Germany & 8 & 4 \\
\hline Greece & 1 & 1 \\
\hline Hong Kong & 10 & 10 \\
\hline India & 19 & 17 \\
\hline Indonesia & 3 & 3 \\
\hline Italy & 2 & 1 \\
\hline Japan & 5 & 5 \\
\hline Malaysia & 16 & 12 \\
\hline Netherlands & 2 & 1 \\
\hline New Zealand & 1 & 1 \\
\hline Pakistan & 3 & 2 \\
\hline Russian Federation & 1 & 1 \\
\hline Singapore & 12 & 9 \\
\hline South Africa & 1 & 1 \\
\hline South Korea & 5 & 5 \\
\hline Spain & 4 & 1 \\
\hline Sweden & 2 & 1 \\
\hline Switzerland & 2 & 1 \\
\hline Taiwan & 2 & 2 \\
\hline Thailand & 4 & 4 \\
\hline United Kingdom & 13 & 4 \\
\hline United States & 16 & 14 \\
\hline Total & 163 & 124 \\
\hline
\end{tabular}


Panel B. Acquiring SWFs

\begin{tabular}{llcc}
\hline SWF & Country & $\begin{array}{c}\text { No. Obs. } \\
\text { (All firms) }\end{array}$ & $\begin{array}{c}\text { No. Obs. } \\
\text { (Regression sample) }\end{array}$ \\
\hline Temasek Holdings & Singapore & 67 & 63 \\
Investment Corporation of Dubai & United Arab Emirates & 22 & 15 \\
Government of Singapore Investment Corp. & Singapore & 16 & 16 \\
Khazanah Nasional Berhad & Malaysia & 12 & 9 \\
Abu Dhabi Investment Authority & United Arab Emirates & 11 & 7 \\
Kuwait Investment Authority & Kuwait & 10 & 2 \\
Qatar Investment Authority & Qatar & 10 & - \\
Mubadala & United Arab Emirates & 6 & 4 \\
SAFE Investment Company & China & 4 & 4 \\
China Investment Corporation & China & 3 & 3 \\
Korea Investment Corporation & South Korea & 1 & 1 \\
Libyan Arab Foreign Investment Company & Libya & 1 & - \\
\hline Total & & $\mathbf{1 6 3}$ & $\mathbf{1 2 4}$ \\
\hline
\end{tabular}




\section{Table 3. Stock Market Reaction to Announcements of SWF Investments}

This table presents the initial stock market reaction to the announcements of SWF investments. Daily abnormal returns measured in local currency are market model adjusted using parameters estimated over a 200 day estimation period. Market returns in local currency are the DataStream International's valueweighted national stock market index in each country. The sample in Panel A includes all 163 announcements during the period between 1982 and 2008. Panel B restricts the sample to equity investments. Panel C excludes firms that receive additional SWF investments following the first one. Panel $\mathrm{D}$ reports CARs for the sample of firms that make it to the cross-sectional regression analysis and Panel $\mathrm{E}$ reports CARs for cross-border SWF investments. Panel F reports results for the period between 1982 and 2005, and Panel G reports results for the post-2005 period. *** indicates significance at the $1 \%$ level, ** indicates significance at the $5 \%$ level, and * indicates significance at the $10 \%$ level.

\begin{tabular}{lclc}
\hline Event Window & CAR (\%) & Test Statistic & Sign Tes \\
\hline Panel A: Entire Sample, 163 events from 135 firms & & \\
$(0,+1)$ & 1.94 & $4.22^{* * *}$ & $4.31^{* * *}$ \\
$(-1,+1)$ & 2.15 & $4.17^{* * *}$ & $3.36^{* * *}$ \\
$(-2,+2)$ & 2.43 & $4.07^{* * *}$ & $4.61^{* * *}$
\end{tabular}

Panel B: Equity investments only, 145 events from 118 firms

$\begin{array}{llll}(0,+1) & 2.06 & 4.04^{* * *} & 4.11^{* * *} \\ (-1,+1) & 2.28 & 4.06^{* * *} & 3.27^{* * *} \\ (-2,+2) & 2.61 & 4.04^{* * *} & 4.77^{* * *}\end{array}$

Panel C: First investment in firm only, 131 events from 131 firms

$\begin{array}{llll}(0,+1) & 2.16 & 4.04^{* * *} & 3.75^{* * *} \\ (-1,+1) & 2.52 & 4.17^{* * *} & 3.03^{* * *} \\ (-2,+2) & 2.71 & 3.84^{* * *} & 4.08^{* * *}\end{array}$

Panel D: Regression Sample, 124 events from 106 firms

$\begin{array}{llll}(0,+1) & 1.46 & 3.14^{* * *} & 3.01^{* * *} \\ (-1,+1) & 1.41 & 2.63^{* * *} & 2.06^{* *} \\ (-2,+2) & 1.63 & 2.45^{* *} & 2.84^{* * *}\end{array}$

Panel E: Cross-Border Investments, 148 events from 122 firms

$\begin{array}{llll}(0,+1) & 1.70 & 3.72^{* * *} & 3.70^{* * *} \\ (-1,+1) & 1.84 & 3.56^{* * *} & 2.98^{* * *} \\ (-2,+2) & 2.07 & 3.54^{* * *} & 3.80^{* * *}\end{array}$

Panel F: Investments between 1982 and 2005, 66 events from 57 firms

$\begin{array}{llll}(0,+1) & 1.04 & 1.99^{* *} & 2.15^{* *} \\ (-1,+1) & 1.26 & 1.75^{*} & 2.14^{* *} \\ (-2,+2) & 1.30 & 1.46 & 2.64^{* * *}\end{array}$

Panel G: Investments between 2006 and 4/2008, 97 events from 82 firms

\begin{tabular}{llll}
$(0,+1)$ & 2.56 & $3.74 * * *$ & $3.82 * * *$ \\
$(-1,+1)$ & 2.75 & $3.87 * * *$ & $2.59 * * *$ \\
$(-2,+2)$ & 3.20 & $4.04 * * *$ & $3.81 * * *$ \\
\hline
\end{tabular}




\section{Table 4. Summary Statistics for SWFs and Target Firms}

This table presents the descriptive statistics for variables used in the cross-sectional analysis. Score is an index based on the cumulative ranking of four major characteristics of SWFs: their transparency and accountability, governance, structure, and behavior. Transparency is an index of variables that proxy for the disclosure practices of SWFs and the degree of rigorousness of the auditing of their activities and performance. Higher values of this index represent more transparency for SWFs. Governance is based on a set of variables that proxy for the existence of investment guidelines and the role of the government and SWF managers in setting and executing them. SWFs with higher values of governance are characterized in general as better governed and have more disclosure on their governance environment. Structure is an index of variables that proxy for how well and clearly SWFs are structured such as their organizational ties with the government budget and international reserves. Higher values of this index correspond to clearer guidelines for the structure and scope of SWF activities. Behavior is related to a set of policies on how the investments are made, such as the speed of adjustment in their portfolios and the use of leverage and derivatives. Higher values of behavior indicate that in general the SWF has more advanced investment and risk management strategies in place. These indexes are obtained from Truman (2008). Transparent is the transparency index developed at the SWF Institute on the degree of transparency of SWFs. Higher values of this index represent better transparency for SWFs. SWF age is the number of years since the SWF's inception. SWF size is the dollar value of assets under the control of the SWF, measured in billion \$US. If SWF size is reported as a range in Table 1 , we use the midpoint. $\Delta$ Common Law refers to the difference between the common law indicator of SWF and the target firm, where common law is a dummy variable that equals one for firms or SWFs located in countries with an English legal origin. $\Delta$ Stock Market Cap / GDP is the difference in the ratio of stock market capitalization to GDP between the countries of the SWF and target firm. Assets is total firm assets measured in million \$US. Leverage is long term debt divided by assets. Sales growth is the one-year change in firm sales. ROA is net income divided by assets. Intangible Assets Ratio is the ratio of intangible assets to assets. Missing values of this variable are set to zero. Institutional Ownership is the percentage of shares held by institutional shareholders. These firm-specific variables are from Thompson Financial and Bloomberg. Stake is the percentage of equity acquired by the SWF. Equity is an indicator variable that takes on the value of one for investments in equity securities, and zero for joint-venture investments. Domestic is a dummy variable that equals one if the SWF investment is within the country of the SWF. All the continuous variables are winsorized at one percent. 


\begin{tabular}{|c|c|c|c|c|c|}
\hline Variable & $\mathbf{N}$ & Mean & Median & Min & Max \\
\hline \multicolumn{6}{|l|}{ SWF Characteristics: } \\
\hline Score & 124 & 12.07 & 15 & 3 & 16.75 \\
\hline Transparency & 124 & 5.94 & 8.5 & 0.5 & 8.5 \\
\hline Governance & 124 & 2.016 & 2.5 & 0 & 4 \\
\hline Structure & 124 & 3.891 & 4 & 2 & 6 \\
\hline Behavior & 124 & 0.225 & 0 & 0 & 1.5 \\
\hline Transparent & 124 & 6.234 & 8 & 1 & 9 \\
\hline \multicolumn{6}{|l|}{ SWF Controls: } \\
\hline SWF age & 124 & 23.31 & 30 & 0 & 55 \\
\hline SWF size (\$billion) & 124 & 141.3 & 111 & 7.5 & 562.5 \\
\hline \multicolumn{6}{|c|}{ Investor Protection and Economic Development: } \\
\hline$\Delta$ Common Law & 124 & 0.234 & 0 & -1 & 1 \\
\hline$\Delta$ Stock Market Cap / GDP & 124 & -0.337 & -1.303 & -2.993 & 9.183 \\
\hline \multicolumn{6}{|l|}{ Target Firm Characteristics: } \\
\hline Assets (\$billion) & 124 & 181.2 & 4.8 & 0.04 & 2,942 \\
\hline Leverage & 124 & 0.303 & 0.287 & 0 & 0.814 \\
\hline Sales growth & 124 & 0.179 & 0.162 & -0.462 & 0.763 \\
\hline ROA & 124 & 0.040 & 0.021 & -0.196 & 0.271 \\
\hline Intangible Assets Ratio & 124 & 0.058 & 0.011 & 0 & 0.731 \\
\hline Institutional Ownership & 124 & 0.187 & 0.144 & 0 & 0.698 \\
\hline \multicolumn{6}{|l|}{ Deal Characteristics: } \\
\hline Stake & 124 & 0.106 & 0.052 & 0 & 1 \\
\hline Equity & 124 & 0.887 & 1 & 0 & 1 \\
\hline Domestic & 124 & 0.087 & 0 & 0 & 1 \\
\hline
\end{tabular}




\section{Table 5. Determinants of the Market Reaction to Announcements of SWF Investments}

This table presents OLS regressions of the impact of various firm, SWF, deal, and country characteristics on the magnitude of the stock market reaction to the announcements of SWF investments. Dependent variable is the reported CAR in Table 3 for the $(0,1)$ event window. Variable definitions are reported in Table 4. In parentheses are $t$-statistics based on standard errors adjusted for country clustering and heteroskedasticity (Rogers, 1993). All regressions control for year and industry fixed effects, whose coefficient estimates are suppressed. $* * *$ indicates significance at the $1 \%$ level, $* *$ indicates significance at the $5 \%$ level, and $*$ indicates significance at the $10 \%$ level.

\begin{tabular}{|c|c|c|c|c|c|c|c|}
\hline Variable & (1) & (2) & (3) & (4) & (5) & (6) & (7) \\
\hline \multicolumn{8}{|l|}{ SWF Characteristics: } \\
\hline Score & $\begin{array}{l}0.003 * * \\
{[2.420]}\end{array}$ & - & - & - & - & - & - \\
\hline Transparency & - & $\begin{array}{c}0.006^{* * *} \\
{[3.417]}\end{array}$ & - & - & - & $\begin{array}{c}0.012 * * * \\
{[2.996]}\end{array}$ & - \\
\hline Governance & - & - & $\begin{array}{l}0.010^{*} \\
{[1.886]}\end{array}$ & - & - & $\begin{array}{c}-0.016 \\
{[-0.852]}\end{array}$ & - \\
\hline Structure & - & - & - & $\begin{array}{c}0.004 \\
{[0.631]}\end{array}$ & - & $\begin{array}{c}0.001 \\
{[0.045]}\end{array}$ & - \\
\hline Behavior & - & - & - & - & $\begin{array}{c}-0.016 \\
{[-0.849]}\end{array}$ & $\begin{array}{c}-0.013 \\
{[-0.532]}\end{array}$ & - \\
\hline Transparent & - & - & - & - & - & - & $\begin{array}{l}0.009 * * \\
{[2.390]}\end{array}$ \\
\hline \multicolumn{8}{|l|}{ SWF Controls: } \\
\hline Log SWF size & $\begin{array}{c}-0.005 \\
{[-0.909]}\end{array}$ & $\begin{array}{c}-0.003 \\
{[-0.508]}\end{array}$ & $\begin{array}{c}-0.006 \\
{[-1.113]}\end{array}$ & $\begin{array}{c}-0.006 \\
{[-1.190]}\end{array}$ & $\begin{array}{l}-0.003 \\
{[0.505]}\end{array}$ & $\begin{array}{c}0.002 \\
{[0.342]}\end{array}$ & $\begin{array}{c}-0.001 \\
{[-0.120]}\end{array}$ \\
\hline Log SWF age & $\begin{array}{c}-0.002 \\
{[-0.238]}\end{array}$ & $\begin{array}{c}-0.008 \\
{[-1.228]}\end{array}$ & $\begin{array}{c}0.003 \\
{[0.387]}\end{array}$ & $\begin{array}{c}0.005 \\
{[0.665]}\end{array}$ & $\begin{array}{c}0.003 \\
{[0.333]}\end{array}$ & $\begin{array}{l}-0.018^{*} \\
{[-1.940]}\end{array}$ & $\begin{array}{c}-0.010 \\
{[-1.171]}\end{array}$ \\
\hline \multicolumn{8}{|c|}{ Investor Protection and Economic Development: } \\
\hline$\Delta$ Common Law & $\begin{array}{c}-0.006 \\
{[-0.425]}\end{array}$ & $\begin{array}{c}-0.004 \\
{[-0.339]}\end{array}$ & $\begin{array}{c}-0.005 \\
{[-0.361]}\end{array}$ & $\begin{array}{c}-0.009 \\
{[-0.745]}\end{array}$ & $\begin{array}{c}-0.010 \\
{[-0.747]}\end{array}$ & $\begin{array}{l}-0.006 \\
{[0.442]}\end{array}$ & $\begin{array}{c}-0.006 \\
{[-0.491]}\end{array}$ \\
\hline$\Delta$ Stock Market Cap / GDP & $\begin{array}{l}0.003^{* *} \\
{[2.681]}\end{array}$ & $\begin{array}{l}0.003^{* *} \\
{[2.491]}\end{array}$ & $\begin{array}{l}0.003^{* *} \\
{[2.644]}\end{array}$ & $\begin{array}{l}0.003 * * \\
{[2.523]}\end{array}$ & $\begin{array}{c}0.003^{* *} \\
{[2.143]}\end{array}$ & $\begin{array}{l}0.003 * * \\
{[2.104]}\end{array}$ & $\begin{array}{l}0.003^{* *} \\
{[2.728]}\end{array}$ \\
\hline \multicolumn{8}{|l|}{ Target Firm Characteristics: } \\
\hline Log Assets & $\begin{array}{c}-0.003 \\
{[-1.049]}\end{array}$ & $\begin{array}{c}-0.003 \\
{[-1.228]}\end{array}$ & $\begin{array}{c}-0.003 \\
{[-1.022]}\end{array}$ & $\begin{array}{c}-0.002 \\
{[-0.795]}\end{array}$ & $\begin{array}{c}-0.002 \\
{[-0.887]}\end{array}$ & $\begin{array}{c}-0.003 \\
{[-1.281]}\end{array}$ & $\begin{array}{c}-0.003 \\
{[-1.153]}\end{array}$ \\
\hline Leverage & $\begin{array}{c}-0.003 \\
{[-0.086]}\end{array}$ & $\begin{array}{c}-0.006 \\
{[-0.178]}\end{array}$ & $\begin{array}{c}-0.003 \\
{[-0.073]}\end{array}$ & $\begin{array}{c}0.000 \\
{[0.010]}\end{array}$ & $\begin{array}{c}-0.003 \\
{[-0.096]}\end{array}$ & $\begin{array}{c}-0.010 \\
{[-0.356]}\end{array}$ & $\begin{array}{c}-0.015 \\
{[-0.503]}\end{array}$ \\
\hline Sales growth & $\begin{array}{c}-0.032 \\
{[-1.234]}\end{array}$ & $\begin{array}{c}-0.033 \\
{[-1.292]}\end{array}$ & $\begin{array}{c}-0.029 \\
{[-1.169]}\end{array}$ & $\begin{array}{c}-0.034 \\
{[-1.327]}\end{array}$ & $\begin{array}{c}-0.037 \\
{[-1.454]}\end{array}$ & $\begin{array}{c}-0.041 \\
{[-1.357]}\end{array}$ & $\begin{array}{c}-0.037 \\
{[-1.228]}\end{array}$ \\
\hline ROA & $\begin{array}{c}0.137 \\
{[1.322]}\end{array}$ & $\begin{array}{c}0.132 \\
{[1.270]}\end{array}$ & $\begin{array}{c}0.129 \\
{[1.274]}\end{array}$ & $\begin{array}{c}0.131 \\
{[1.353]}\end{array}$ & $\begin{array}{c}0.112 \\
{[1.365]}\end{array}$ & $\begin{array}{l}0.122 \\
{[1.271]}\end{array}$ & $\begin{array}{c}0.130 \\
{[1.509]}\end{array}$ \\
\hline Intangible Assets Ratio & $\begin{array}{c}0.118 \\
{[1.503]}\end{array}$ & $\begin{array}{c}0.122 \\
{[1.612]}\end{array}$ & $\begin{array}{c}0.106 \\
{[1.334]}\end{array}$ & $\begin{array}{c}0.101 \\
{[1.207]}\end{array}$ & $\begin{array}{c}0.079 \\
{[0.920]}\end{array}$ & $\begin{array}{c}0.118 \\
{[1.406]}\end{array}$ & $\begin{array}{c}0.086 \\
{[1.108]}\end{array}$ \\
\hline Institutional Ownership & $\begin{array}{l}0.049^{*} \\
{[1.927]}\end{array}$ & $\begin{array}{l}0.053^{*} \\
{[1.987]}\end{array}$ & $\begin{array}{l}0.048^{*} \\
{[1.931]}\end{array}$ & $\begin{array}{l}0.045^{*} \\
{[1.766]}\end{array}$ & $\begin{array}{l}0.048^{*} \\
{[1.814]}\end{array}$ & $\begin{array}{l}0.058^{*} \\
{[1.948]}\end{array}$ & $\begin{array}{c}0.056^{* *} \\
{[2.202]}\end{array}$ \\
\hline
\end{tabular}




\begin{tabular}{lccccccc} 
Deal Characteristics: & & & & & & \\
Stake & 0.041 & 0.039 & 0.043 & 0.047 & 0.051 & 0.041 & 0.062 \\
& {$[0.709]$} & {$[0.692]$} & {$[0.738]$} & {$[0.807]$} & {$[0.868]$} & {$[0.714]$} & {$[1.395]$} \\
Equity & 0.006 & 0.002 & 0.007 & 0.009 & 0.008 & -0.001 & 0.002 \\
& {$[0.338]$} & {$[0.144]$} & {$[0.398]$} & {$[0.513]$} & {$[0.443]$} & {$[-0.092]$} & {$[0.141]$} \\
\multicolumn{1}{c}{ Domestic } & 0.033 & 0.036 & 0.033 & 0.030 & 0.033 & 0.041 & 0.042 \\
& {$[0.835]$} & {$[0.907]$} & {$[0.782]$} & {$[0.785]$} & {$[0.836]$} & {$[1.066]$} & {$[1.606]$} \\
Intercept & 0.003 & -0.096 & 0.012 & -0.088 & -0.075 & 0.045 & -0.001 \\
& {$[0.078]$} & {$[-1.216]$} & {$[0.299]$} & {$[-1.173]$} & {$[-0.956]$} & {$[1.179]$} & {$[-0.020]$} \\
Industry Controls & Yes & Yes & Yes & Yes & Yes & Yes & Yes \\
Year Controls & Yes & Yes & Yes & Yes & Yes & Yes & Yes \\
Observations & 124 & 124 & 124 & 124 & 124 & 124 & 124 \\
R-squared & 0.535 & 0.548 & 0.530 & 0.517 & 0.519 & 0.559 & 0.552 \\
\hline
\end{tabular}




\section{Table 6. The Impact of Transparency, Governance, Structure, and Behavior of SWFs}

This table presents OLS regressions of the impact of SWF transparency, governance, structure, and behavior on the magnitude of the stock market reaction to the announcements of SWF investments. Dependent variable is the reported CAR in Table 3 for the $(0,+1)$ event window. Each row represents a separate regression in which an individual component of the Truman (2008) scoreboard is included in addition to all the firm, deal, country, and other SWF characteristics as well as year and industry fixed effects reported in Table 5. We only report the coefficient estimate on the individual component of the SWF indexes for brevity. Results are not reported for individual components that are either all same across SWFs in the sample or are non-zero only for one SWF. Variable definitions are reported in the Appendix. In parentheses are $t$-statistics based on standard errors adjusted for country clustering and heteroskedasticity (Rogers, 1993). ${ }^{* * *}$ indicates significance at the $1 \%$ level, $* *$ indicates significance at the $5 \%$ level, and * indicates significance at the $10 \%$ level.

\begin{tabular}{|c|c|c|c|c|c|c|}
\hline Variable & Coefficient & t-stats & $\begin{array}{l}\text { No } \\
\text { obs. }\end{array}$ & $\begin{array}{c}\text { R- } \\
\text { squared }\end{array}$ & $\begin{array}{l}\text { Firm, Deal, } \\
\text { Country, and other } \\
\text { SWF factors }\end{array}$ & $\begin{array}{c}\text { Industry } \\
\text { and Year } \\
\text { Effects }\end{array}$ \\
\hline \multicolumn{7}{|l|}{ Transparency } \\
\hline Annual report & $0.058 * * *$ & 4.274 & 124 & 0.559 & Included & Included \\
\hline Regular audit & 0.021 & 1.204 & 124 & 0.522 & Included & Included \\
\hline Published audit & $0.043 * * *$ & 4.400 & 124 & 0.564 & Included & Included \\
\hline Independent audit & $0.033 * *$ & 2.540 & 124 & 0.536 & Included & Included \\
\hline Location & $0.050 * *$ & 2.782 & 124 & 0.539 & Included & Included \\
\hline Specific & $0.073 * * *$ & 3.419 & 124 & 0.552 & Included & Included \\
\hline Returns & $0.044 * *$ & 3.310 & 124 & 0.546 & Included & Included \\
\hline Size of fund & $0.033 * *$ & 2.652 & 124 & 0.542 & Included & Included \\
\hline Categories & 0.026 & 0.508 & 124 & 0.517 & Included & Included \\
\hline Benchmarks & -0.008 & -0.317 & 124 & 0.516 & Included & Included \\
\hline Credit ratings & $-0.046 * *$ & -2.092 & 124 & 0.534 & Included & Included \\
\hline \multicolumn{7}{|l|}{ Governance } \\
\hline Role of managers & $0.038 * * *$ & 3.239 & 124 & 0.550 & Included & Included \\
\hline Decisions by managers & $0.031 * *$ & 2.085 & 124 & 0.530 & Included & Included \\
\hline Corporate responsibility & $0.067 * * *$ & 4.136 & 124 & 0.557 & Included & Included \\
\hline Role of government & -0.016 & -0.687 & 124 & 0.518 & Included & Included \\
\hline \multicolumn{7}{|l|}{ Structure } \\
\hline Objective & $0.082 * * *$ & 2.847 & 124 & 0.534 & Included & Included \\
\hline Source of funding & $0.039 * *$ & 2.471 & 124 & 0.541 & Included & Included \\
\hline Integrated with budget & -0.024 & -1.476 & 124 & 0.529 & Included & Included \\
\hline Guidelines followed & -0.017 & -0.954 & 124 & 0.521 & Included & Included \\
\hline Investment strategy & $0.075 * * *$ & 3.802 & 124 & 0.562 & Included & Included \\
\hline Changing the structure & -0.018 & -0.741 & 124 & 0.519 & Included & Included \\
\hline Separate & 0.017 & 0.954 & 124 & 0.521 & Included & Included \\
\hline \multicolumn{7}{|l|}{$\underline{\text { Behavior }}$} \\
\hline No controlling stakes & -0.001 & -0.020 & 124 & 0.515 & Included & Included \\
\hline Derivatives & -0.032 & -1.127 & 124 & 0.522 & Included & Included \\
\hline
\end{tabular}




\section{Table 7. Robustness Tests}

This table presents results for the impact of various SWF characteristics on the magnitude of the stock market reaction to the announcements of SWF investments using alternative samples and estimation procedures while controlling for firm, SWF, deal, and country characteristics. Dependent variable is the reported CAR in Table 3 for the $(0,+1)$ event window unless otherwise noted. Panel A reports regression estimates based on the entire sample. Panel B reports regression estimates based on various subsamples of firms. Variable definitions are reported in Table 4. In parentheses are $t$ statistics based on standard errors adjusted for country clustering and heteroskedasticity (Rogers, 1993). The overall R-squared value is reported for random country effects estimation in Panel B. All regressions control for year and industry fixed effects, whose coefficient estimates are suppressed. $* * *$ indicates significance at the $1 \%$ level, $* *$ indicates significance at the $5 \%$ level, and $*$ indicates significance at the $10 \%$ level.

Panel A. Robustness tests based on the entire sample

\begin{tabular}{|c|c|c|c|c|c|c|c|c|}
\hline Row & Variable & Coefficient & t-stats & Nature of Robustness Check & $\begin{array}{l}\text { Firm, Deal, } \\
\text { Country, and } \\
\text { other SWF factors }\end{array}$ & $\begin{array}{l}\text { Industry } \\
\text { and Year } \\
\text { Effects }\end{array}$ & $\begin{array}{l}\text { No } \\
\text { Obs. }\end{array}$ & $\begin{array}{l}\text { R- } \\
\text { Squared }\end{array}$ \\
\hline 1 & Transparency & $0.006^{* *}$ & 2.329 & Random Country Effects Estimation & Included & Included & 124 & 0.545 \\
\hline 2 & $\begin{array}{l}\text { Common factor for } \\
\text { Transparency }\end{array}$ & $0.009 * * *$ & 4.042 & $\begin{array}{l}\text { Common Factor Extracted from a Principal } \\
\text { Component Analysis for Transparency }\end{array}$ & Included & Included & 124 & 0.557 \\
\hline 3 & $\begin{array}{l}\text { Common factor for } \\
\text { Score }\end{array}$ & $0.006 * * *$ & 4.020 & $\begin{array}{l}\text { Common Factor Extracted from a Principal } \\
\text { Component Analysis for Score }\end{array}$ & Included & Included & 124 & 0.559 \\
\hline 4 & $\begin{array}{l}\text { Dummy for Private } \\
\text { Industry Directors }\end{array}$ & $0.031 * * *$ & 3.782 & An Alternative Transparency Index & Included & Included & 119 & 0.576 \\
\hline 5 & $\begin{array}{l}\text { Percent of Private } \\
\text { Industry Directors }\end{array}$ & $0.091 * * *$ & 3.073 & An Alternative Transparency Index & Included & Included & 119 & 0.571 \\
\hline 6 & Transparency & $0.008 * * *$ & 3.612 & Lagged Values of Firm Characteristics & Included & Included & 111 & 0.628 \\
\hline 7 & Transparency & $0.006 * * *$ & 3.826 & Dependent variable $=$ CAR $(-1,+1)$ window & Included & Included & 124 & 0.562 \\
\hline 8 & Transparency & $0.008 * * *$ & 3.44 & $\Delta$ Common Law replaced with $\Delta$ Disclosure & Included & Included & 124 & 0.552 \\
\hline
\end{tabular}


Panel B. Robustness tests based on sub-samples

\begin{tabular}{|c|c|c|c|c|c|c|c|c|}
\hline Row & Variable & Coefficient & T-stats & Nature of Robustness Check & $\begin{array}{l}\text { Firm, Deal, } \\
\text { Country, and } \\
\text { other SWF factors }\end{array}$ & $\begin{array}{l}\text { Industry } \\
\text { and Year } \\
\text { Effects }\end{array}$ & $\begin{array}{l}\text { No } \\
\text { Obs. }\end{array}$ & $\begin{array}{l}\text { R- } \\
\text { Squared }\end{array}$ \\
\hline 1 & Transparency & $0.006^{* *}$ & 2.769 & Contaminated Events Excluded & Included & Included & 116 & 0.565 \\
\hline 2 & Transparency & $0.008^{*}$ & 1.729 & Investments by Temasek Holdings Excluded & Included & Included & 58 & 0.665 \\
\hline 3 & Transparency & $0.006 * *$ & 2.364 & Only Equity Investments & Included & Included & 110 & 0.584 \\
\hline 4 & Transparency & $0.006 * * *$ & 3.002 & Only Cross-Border Investments & Included & Included & 113 & 0.538 \\
\hline 5 & Transparency & $0.005 * *$ & 2.333 & Firms with Multiple Investments Excluded & Included & Included & 100 & 0.613 \\
\hline 6 & Transparency & $0.009 * *$ & 2.286 & Banks Excluded & Included & Included & 90 & 0.602 \\
\hline
\end{tabular}




\section{Table 8. Changes in Target Firms' Operational Performance and Governance around SWF Investments}

This table compares the operational performance and corporate governance of target firms around SWF investments. The control sample is matched with target firms with respect to country, industry, and profitability in the year prior to the SWF investment. The profitability measure used in matching firms is the operating income to assets (sales) ratio when comparing changes in operating income to assets (sales) ratio, and the ROA when comparing ROA, sales growth, and CEO turnover. Panel A displays results for the $\mathrm{t}-1$ to $t+1$ window and Panel B displays results for the $t-1$ to $t+3$ window, where $t$ is defined as the year of SWF investment in the sample firm. Operating income is defined as earnings before interest and taxes. CEO turnover is a binary variable that takes on the value one if the CEO is changed during the event window. If a firm has multiple SWF investments over time, we only include the observation associated with the first SWF investment in this analysis. $* * *$ indicates significance at the $1 \%$ level, $* *$ indicates significance at the $5 \%$ level, and * indicates significance at the $10 \%$ level.

Panel A. Comparisons from one year before the SWF investment to one year after the SWF investment

\begin{tabular}{|c|c|c|c|c|}
\hline Variable name & $\begin{array}{l}\text { Mean (median) } \\
\text { for target firms } \\
(\%)\end{array}$ & $\begin{array}{l}\text { Mean (median) } \\
\text { for control firms } \\
(\%)\end{array}$ & $\begin{array}{l}\text { t-stats (Wilcoxon } \\
\text { z-stats) on paired } \\
\text { difference }\end{array}$ & $\begin{array}{l}\text { Number of } \\
\text { matched } \\
\text { pairs }\end{array}$ \\
\hline \multicolumn{5}{|c|}{ Operational Performance and Investments } \\
\hline Operating income/Assets & $\begin{array}{l}-0.950 \\
(0.086)\end{array}$ & $\begin{array}{c}-0.814 \\
(-0.014)\end{array}$ & $\begin{array}{c}-0.120 \\
(-0.944)\end{array}$ & 59 \\
\hline Operating income/Sales & $\begin{array}{l}-7.366 \\
(0.028)\end{array}$ & $\begin{array}{l}-3.836 \\
(0.873)\end{array}$ & $\begin{array}{c}-0.575 \\
(-1.026)\end{array}$ & 58 \\
\hline ROA & $\begin{array}{c}-0.407 \\
(0.111)\end{array}$ & $\begin{array}{c}0.247 \\
(0.144)\end{array}$ & $\begin{array}{c}-1.078 \\
(-1.016)\end{array}$ & 60 \\
\hline Sales growth & $\begin{array}{c}-13.936 \\
(-11.691)\end{array}$ & $\begin{array}{l}-15.190 \\
(-3.321)\end{array}$ & $\begin{array}{c}0.207 \\
(0.198)\end{array}$ & 44 \\
\hline Capital Expenditures/Sales & $\begin{array}{c}6.671 \\
(0.273)\end{array}$ & $\begin{array}{c}0.259 \\
(-0.001)\end{array}$ & $\begin{array}{c}0.763 \\
(0.475)\end{array}$ & 46 \\
\hline \multicolumn{5}{|l|}{ Governance Environment } \\
\hline Unconditional CEO turnover & $\begin{array}{c}-11.3^{* *} \\
(-)\end{array}$ & $\begin{array}{c}-16.7^{* * * *} \\
(-)\end{array}$ & $\begin{array}{c}0.554 \\
(-)\end{array}$ & 66 \\
\hline $\begin{array}{l}\text { CEO turnover for Operating } \\
\text { income/Assets }=<\text { sample } \\
\text { median }\end{array}$ & $\begin{array}{c}0 \\
(-)\end{array}$ & $\begin{array}{l}-12.5 \\
(-)\end{array}$ & $\begin{array}{c}0.367 \\
(-)\end{array}$ & 15 \\
\hline $\begin{array}{l}\text { CEO turnover for Operating } \\
\text { income/Assets }>\text { sample } \\
\text { median }\end{array}$ & $\begin{array}{c}-25.0^{* * *} \\
(-)\end{array}$ & $\begin{array}{l}13.3 \\
(-)\end{array}$ & $\begin{array}{c}-2.09^{* *} \\
(-)\end{array}$ & 14 \\
\hline
\end{tabular}


Panel B. Comparisons from one year before the SWF investment to three years after the SWF investment

\begin{tabular}{|c|c|c|c|c|}
\hline Variable name & $\begin{array}{c}\text { Mean (median) } \\
\text { for target firms } \\
(\%)\end{array}$ & $\begin{array}{c}\text { Mean (median) } \\
\text { for control firms } \\
(\%)\end{array}$ & $\begin{array}{l}\text { t-stats (Wilcoxon } \\
\text { z-stats) on paired } \\
\text { difference }\end{array}$ & $\begin{array}{l}\text { Number of } \\
\text { matched } \\
\text { pairs }\end{array}$ \\
\hline \multicolumn{5}{|c|}{ Operational Performance and Investments } \\
\hline Operating income/Assets & $\begin{array}{c}-1.286 \\
(0.458)\end{array}$ & $\begin{array}{c}0.985 \\
(0.763)\end{array}$ & $\begin{array}{c}-1.479 \\
(-1.512)\end{array}$ & 21 \\
\hline Operating income/Sales & $\begin{array}{l}-0.013 \\
(2.668)\end{array}$ & $\begin{array}{c}2.746 \\
\left(4.511^{*}\right)\end{array}$ & $\begin{array}{c}-0.802 \\
(-1.025)\end{array}$ & 21 \\
\hline ROA & $\begin{array}{l}-1.067 \\
(0.285)\end{array}$ & $\begin{array}{c}1.415 \\
(0.297)\end{array}$ & $\begin{array}{c}-1.619 \\
(-1.303)\end{array}$ & 20 \\
\hline Sales growth & $\begin{array}{c}-1.915 \\
(-3.879)\end{array}$ & $\begin{array}{c}-5.021 \\
(-5.395)\end{array}$ & $\begin{array}{c}0.301 \\
(0.592)\end{array}$ & 17 \\
\hline Capital Expenditures/Sales & $\begin{array}{c}3.600 \\
(0.586)\end{array}$ & $\begin{array}{c}-7.750 \\
(-0.459)\end{array}$ & $\begin{array}{c}2.184^{* *} \\
(1.988)^{* *}\end{array}$ & 15 \\
\hline \multicolumn{5}{|l|}{ Governance Environment } \\
\hline Unconditional CEO turnover & $\begin{array}{l}3.7 \\
(-)\end{array}$ & $\begin{array}{l}-4.0 \\
(-)\end{array}$ & $\begin{array}{c}0.569 \\
(-)\end{array}$ & 25 \\
\hline $\begin{array}{l}\text { CEO turnover for Operating } \\
\text { income/Assets }<=\text { sample } \\
\text { median }\end{array}$ & $\begin{array}{l}-16.7 \\
(-)\end{array}$ & $\begin{array}{l}63.2 \\
(-)\end{array}$ & $\begin{array}{c}-0.542 \\
(-)\end{array}$ & 6 \\
\hline $\begin{array}{l}\text { CEO turnover for Operating } \\
\text { income/Assets }>\text { sample } \\
\text { median }\end{array}$ & $\begin{array}{l}25.0 \\
(-)\end{array}$ & $\begin{array}{c}-25.0 \\
(-)\end{array}$ & $\begin{array}{c}-1.000 \\
(-)\end{array}$ & 4 \\
\hline
\end{tabular}




\section{Appendix. Sovereign Wealth Fund Data}

This table provides detailed information about the SWF data. Panel A provides variable definitions for the SWF scoreboard developed by Truman (2008) and Panel B reports the related data. Panel C provides data information on the SWF Institute's transparency index, transparent, for our regression sample of SWFs. The index was developed at the Sovereign Wealth Fund Institute. The composition of this index is as follows. A SWF earns one additional point if the fund provides history including reason for creation, origins of wealth, and government ownership structure; it provides up-to-date independently audited annual reports; it provides ownership percentage of company holdings, and geographic locations of holdings; it provides total portfolio market value, returns, and management compensation; it provides guidelines in reference to ethical standards, investment policies, and enforcer of guidelines; provides clear strategies and objectives; if applicable, it clearly identifies subsidiaries and contact information; if applicable, it identifies external managers; it manages its own web site; and if the fund provides main office location address and contact information such as telephone and fax. The data are available at http://www.swfinstitute.org/research/transparencyindex.php.

Panel A. Definitions of the SWF Scoreboard from Truman (2008)

\begin{tabular}{|c|c|}
\hline Variable & Definition \\
\hline \multicolumn{2}{|c|}{ Transparency and Accountability } \\
\hline Categories & Do regular reports on investments by the SWF include information on the categories of investments? \\
\hline Benchmarks & Does the SWF investment strategy use benchmarks? \\
\hline Credit ratings & Does the SWF investment strategy limit investments based on credit ratings? \\
\hline Mandates & Are the holders of investment mandates identified? \\
\hline Size of fund & $\begin{array}{l}\text { Does the SWF regularly report the size of the fund? Partial credit is given where a SWF states that it is "at least" } \\
\text { a certain size. }\end{array}$ \\
\hline Returns & Do regular reports on investments by the SWF include information on the returns it earns? \\
\hline Location & Does the SWF report the geographic location of investments? Partial credit is given for listing broad regions. \\
\hline Specific & $\begin{array}{l}\text { Does the SWF provide information on specific investments? Partial credit is given if the SWF identifies only } \\
\text { "significant" investments. }\end{array}$ \\
\hline Currency composition & $\begin{array}{l}\text { Does the SWF report the currency composition of its investments? Partial credit is given for listing broad } \\
\text { groups of currencies. }\end{array}$ \\
\hline Annual report & $\begin{array}{l}\text { Does the SWF provide an annual report? Partial credit is given for annual reports that contain little or no } \\
\text { information on SWF activities. }\end{array}$ \\
\hline Quarterly report & $\begin{array}{l}\text { Does the SWF provide quarterly reports? Partial credit is given for reports that contain little or no information } \\
\text { on SWF activities. }\end{array}$ \\
\hline Regular audit & Is the SWF subjected to a regular annual audit? \\
\hline Published & Is the audit published? \\
\hline
\end{tabular}


Independent

\section{Structure}

Objective

Source of funding

Use

Integrated with budget

Guidelines followed

Investment strategy

Changing the structure

Separate

\section{Governance}

Role of government

Role of managers

Decisions by managers

Guidelines for corporate responsibility

Ethical guidelines

\section{Behavior}

Speed of adjustment

Size of stakes

No controlling stakes

Leverage

Derivatives

Hedging
Is the audit independent?

Is the SWF's objective clearly communicated?

Is the SWF's source of funding clearly specified?

Is the nature of the subsequent use of the principal and earnings in the fund clearly stated?

Is the SWF integrated with the budget?

Are the guidelines for fiscal treatment followed without frequent adjustment?

Is the overall investment strategy clearly communicated?

Is the procedure for changing the SWF structure clear?

Is the SWF separate from the country's international reserves?

Is the role of the government in setting investment strategy for the SWF clearly established?

Is the role of the managers in executing investment strategy clearly established?

Are decisions on specific investments made by the managers?

Does the SWF have publicly available guidelines for corporate responsibility?

Does the SWF have ethical guidelines that it follows?

Does the SWF indicate the nature and speed of adjustment in its portfolio?

Does the SWF have limits on the size of its stakes?

Does the SWF not take controlling stakes?

Does the SWF have a policy on the use of leverage?

Does the SWF have a policy on the use of derivatives?

Are derivatives used primarily for hedging? 
Panel B. The Data for SWF Scoreboard from Truman (2008)

\begin{tabular}{|c|c|c|c|c|c|c|c|c|c|c|c|}
\hline Variable & China & Kuwait & Malaysia & Korea & $\begin{array}{l}\text { Singapore } \\
\text { - GIC }\end{array}$ & $\begin{array}{l}\text { Singapore } \\
\text { - Temasek }\end{array}$ & $\begin{array}{l}\text { UAE - } \\
\text { ADIA }\end{array}$ & $\begin{array}{l}\text { UAE - } \\
\text { Dubai }\end{array}$ & $\begin{array}{c}\text { UAE - } \\
\text { Mubadala }\end{array}$ & $\begin{array}{c}\text { Average } \\
\text { for sample } \\
\text { SWFs }\end{array}$ & $\begin{array}{c}\text { Average } \\
\text { for all } \\
\text { SWFs }\end{array}$ \\
\hline \multicolumn{12}{|l|}{ Transparency and } \\
\hline \multicolumn{12}{|l|}{ Accountability } \\
\hline Categories & 0.5 & 0 & 0.5 & 0.5 & 0.5 & 0.5 & 0.25 & 0.25 & 0 & 0.33 & 0.49 \\
\hline Benchmarks & 0.5 & 0.5 & 1 & 0.5 & 1 & 0.5 & 0.25 & 0 & 0.5 & 0.53 & 0.45 \\
\hline Credit ratings & 0 & 1 & 0 & 1 & 0.5 & 0 & 0 & 0 & 0 & 0.28 & 0.41 \\
\hline Mandates & 0 & 0 & 0 & 0 & 0 & 0 & 0 & 0 & 0 & 0.00 & 0.47 \\
\hline Size of fund & 1 & 1 & 1 & 1 & 0 & 1 & 0 & 0.5 & 0 & 0.61 & 0.72 \\
\hline Returns & 0 & 0.5 & 1 & 0.25 & 0.25 & 1 & 0 & 0 & 0 & 0.33 & 0.44 \\
\hline Location & 0 & 0.25 & 1 & 0 & 0.25 & 1 & 0 & 0.25 & 0 & 0.31 & 0.28 \\
\hline Specific & 0 & 0 & 0.5 & 0 & 0 & 0.5 & 0 & 0 & 0.5 & 0.17 & 0.16 \\
\hline Currency composition & 0 & 0 & 0 & 0 & 0 & 0 & 0 & 0 & 0 & 0.00 & 0.31 \\
\hline Annual report & 0 & 0.5 & 0.5 & 0.5 & 0.5 & 1 & 0 & 0 & 0 & 0.33 & 0.53 \\
\hline Quarterly report & 0 & 0 & 0 & 0 & 0.5 & 0 & 0 & 0 & 0 & 0.06 & 0.38 \\
\hline Regular audit & 0 & 1 & 1 & 1 & 1 & 1 & 0 & 0 & 0 & 0.56 & 0.62 \\
\hline Published & 0 & 0 & 0 & 0.5 & 0 & 1 & 0 & 0 & 0 & 0.17 & 0.32 \\
\hline Independent & 0 & 1 & 0 & 1 & 1 & 1 & 0 & 0 & 0 & 0.44 & 0.57 \\
\hline \multicolumn{12}{|l|}{ Structure } \\
\hline Objective & 1 & 1 & 1 & 1 & 1 & 1 & 0.5 & 1 & 1 & 0.94 & 0.94 \\
\hline Source of funding & 1 & 1 & 1 & 1 & 0.5 & 1 & 0 & 0.5 & 0 & 0.67 & 0.84 \\
\hline Use & 0 & 0 & 0 & 0 & 1 & 0 & 0 & 0 & 0 & 0.11 & 0.54 \\
\hline Integrated with budget & 0 & 1 & 0 & 1 & 1 & 0 & 0 & 0 & 0 & 0.33 & 0.60 \\
\hline Guidelines followed & 0 & 0 & 0 & 1 & 1 & 0 & 0 & 0 & 0 & 0.22 & 0.44 \\
\hline Investment strategy & 1 & 1 & 0.5 & 1 & 0.5 & 1 & 0.5 & 0.5 & 0.5 & 0.72 & 0.60 \\
\hline Changing the structure & 0 & 1 & 0 & 1 & 0 & 0 & 0 & 0 & 1 & 0.33 & 0.68 \\
\hline
\end{tabular}


Separate

$1 \quad 1 \quad 1$

Governance

Role of government

Role of managers

Decisions by managers

\begin{tabular}{ccccccccccc}
1 & 1 & 0.5 & 1 & 0.5 & 0 & 0 & 0 & 0 & 0.44 & 0.63 \\
1 & 1 & 1 & 1 & 0.5 & 1 & 0 & 0.5 & 0.5 & 0.72 & 0.72 \\
0 & 1 & 0.5 & 1 & 1 & 1 & 0 & 0 & 0 & 0.50 & 0.47 \\
0.5 & 0 & 0.5 & 0 & 0 & 0.5 & 0 & 0 & 0 & 0.17 & 0.12 \\
0 & 1 & 0 & 0 & 0 & 0 & 0 & 0 & 0 & 0.11 & 0.09 \\
& & & & & & & & & & \\
0 & 0 & 0 & 0.5 & 0 & 0 & 0 & 0 & 0 & 0.06 & 0.10 \\
0 & 0 & 0 & 0 & 0 & 0 & 0.25 & 0 & 0 & 0.03 & 0.15 \\
1 & 0 & 0 & 0 & 0.5 & 0 & 0.25 & 0 & 0 & 0.19 & 0.46 \\
0 & 0 & 0 & 0 & 0 & 0 & 0 & 0 & 0 & 0.00 & 0.13 \\
0 & 0 & 0 & 1 & 0.5 & 0 & 0 & 0 & 0 & 0.17 & 0.35 \\
0 & 0 & 0 & 0 & 0 & 0 & 0 & 0 & 0 & 0.00 & 0.26 \\
\hline
\end{tabular}

Guidelines for corporate

responsibility

Ethical guidelines

\section{Behavior}

Speed of adjustment

Size of stakes

No controlling stakes

Leverage

Derivatives

Hedging 
Panel C. Data for the SWF Institute's Transparency Index

\begin{tabular}{llc}
\hline SWF & Country & $\begin{array}{c}\text { The Score on } \\
\text { Transparent }\end{array}$ \\
\hline Temasek Holdings & Singapore & 8 \\
Investment Corporation of Dubai & United Arab Emirates & 4 \\
Government of Singapore Investment Corp. & Singapore & 6 \\
Khazanah Nasional Berhad & Malaysia & 4 \\
Abu Dhabi Investment Authority & United Arab Emirates & 3 \\
Kuwait Investment Authority & Kuwait & 6 \\
Mubadala & United Arab Emirates & 6 \\
SAFE Investment Company & China & 2 \\
China Investment Corporation & China & 1 \\
Korea Investment Corporation & South Korea & 9 \\
\hline Average & & $\mathbf{4 . 9}$ \\
\hline
\end{tabular}


${ }^{1}$ See Butt, Shivdasani, Stendevad, and Wyman (2008), Jen (2007), Johnson (2007), Maslakovic (2008), and IMF publication (2008b).

${ }^{2}$ The number of countries with a SWF has increased from fewer than 20 in 2000 to about 40 as of 2008 . For example, China, South Korea, Russia, and Libya have recently initiated a SWF and Indonesia is planning to launch a SWF with an initial endowment of between $\$ 50$ billion and $\$ 150$ billion and Brazil, Iceland, and Japan are debating whether they should also initiate a SWF.

${ }^{3}$ Sudden portfolio adjustments by SWFs may disrupt the functioning of financial markets

${ }^{4}$ Theory provides two main sources of problems with state ownership: political interference (Shleifer and Vishny, 1994), and agency conflicts (Banerjee, 1997; Laffont and Tirole, 1993). In our paper, the involvement of foreign governments adds other concerns as mentioned above.

${ }^{5}$ For instance, until very recently the U.A.E.'s Abu Dhabi Investment Authority only provided an address, telephone, and fax number on their official webpage - no other details of the fund were given. Further, in some cases the ultimate ownership of SWFs is opaque, especially in Middle Eastern countries, aggravating agency problems due to the absence of a principal.

${ }^{6}$ See OECD publication (2008), IMF press release (2008a), IMF publication (2008b), and IWG press release (2008).

${ }^{7}$ Recent investment in Citigroup by Abu Dhabi Investment Authority, Kuwait Investment Authority, and the Government of Singapore Investment Corporation at a time when liquidity was highly needed alleviated concerns among investors regarding the financial strength of the bank.

${ }^{8}$ Karpoff (2001), Black (1990), and Gillian and Starks (2007) provide comprehensive surveys.

${ }^{9}$ For example, see Gupta (2005) and Perotti (1995) for an examination of partial privatizations.

${ }^{10}$ Twenty-five SWFs have formed an international working group, facilitated by the IMF, to develop a set of voluntary best practices and principles (IMF press release, 2008a; IWG press release, 2008). Further, several individual SWFs have recently become more transparent. For example, in July 2006 GIC disclosed its investment results for the first time since its inception (Lee, 2006) and in March 2008 Abu Dhabi sent a letter to U.S. Treasury Secretary Henry Paulsen declaring that the emirate "has never and will never use its investments as a foreign policy tool" (Cummins, 2008).

${ }^{11}$ See, for example, Aizenman and Glick (2007), Blundell-Wignall, Hu, and Yermo (2008), Kern (2007), and U.S. Department of the Treasury publication (2007).

${ }^{12}$ Although the National Stabilization Fund of Taiwan ranks $20^{\text {th }}$ in terms of its assets, we do not include this SWF in Table 1 because it holds exclusively domestic assets (we thank Edwin Truman for pointing this out to us.)

${ }^{13}$ Holdings of foreign official institutions include foreign reserve asset holdings of central banks, holdings of foreign government-sponsored investment funds, and other foreign government institutions. Firm and country-specific data on foreign official investments are not publicly available.

${ }^{14}$ This is a somewhat misleading comparison, since hedge funds and private equity funds tend to be very highly leveraged and SWFs generally use very little leverage, and some of SWFs' assets are invested in hedge funds and private equity funds (see IMF publication, 2008b).

${ }^{15}$ SWFs also differ from sovereign pension funds (SPFs). While government-owned, SPFs have explicit liabilities (i.e., the pensions of workers) and must ultimately report to pension holders. Consequently, we consider CalPERS a SPF (because it bears responsibility to the public workers of California), but we consider Norway's Government Pension Fund - Global to be a SWF (despite its name, Norway's fund has no explicit pension liabilities and is ultimately only accountable to the government of Norway).

${ }^{16}$ Even the objectives of SWFs are not disclosed in some countries.

${ }^{17}$ These SWFs control about 85 percent of the total SWF assets.

${ }^{18}$ For robustness, we also include the world market index obtained from Datastream International as an additional benchmark in estimating abnormal returns. We find that our results become slightly more significant, both in economic and statistical terms.

${ }^{19}$ This number is calculated as the average CAR reported in Table 3 for the $(0,+1)$ window multiplied by the average stock market capitalization of sample firms. 
${ }^{20}$ Existing shareholders of the target firm are not the only beneficiaries of the increase in target firms' value due to the announcement of SWF investments. The average CAR for the $(0,+1)$ window is about 1.4 percent in cases which the announcement follows the actual SWF investment in the target firm. This reaction is statistically significant, suggesting that some of the benefits do accrue to the SWF.

${ }^{21}$ This result is robust to the elimination of banks from the analysis, suggesting it is not due to the clustering of SWF investments in banks in the last two years.

${ }^{22}$ Truman (2008) also rates 10 SPFs.

${ }^{23}$ The data are available at http://www.swfinstitute.org/research/transparencyindex.php.

${ }^{24} \mathrm{We}$ also include several other control variables such as free cash flows, dividend yields, interest coverage ratio, and whether the target firm had a loss in the previous year. We find that none of these variables are statistically significant at conventional levels in our cross-sectional regressions. Our main results are also robust to the inclusion of these variables.

${ }^{25}$ Non-equity investments do not have equity ownership, for which stake is set to zero.

${ }^{26}$ The coefficient on governance changes sign in the final column. This could be due to either transparency subsuming the positive impact of governance on CARs, or a possible multicollinearity. The correlation between transparency and governance is high and statistically significant. We check the average variance inflation factor and find that multicollinearity is not substantial in the model. Further, we extract the common factor for each of the four components using a principal components analysis, which reduces the pairwise correlations among the four components significantly. Our results hold when we replace the original index values for the four components from Truman (2008) with the common factors (these results are reported in later sections).

${ }^{27}$ When we replace stake with several dummy variables corresponding to different ownership thresholds such as stake $<5 \%$ dummy and stake $>=10 \%$ dummy, we find that none of the equity ownership dummies are significant. Regarding the legal environment, we also create three dummy variables to replace $\Delta$ Common Law (dummies for a common law SWF acquiring a civil law firm, a civil law SWF acquiring a common law firm, and a common law SWF acquiring a common law firm) and re-run the regressions. None of these dummy variables are significant at conventional levels although all of them have positive coefficients.

${ }^{28} \mathrm{We}$ do not include the individual components in the same regression because they are highly correlated with each other within the same sub-index. Further, results are not reported for individual components that are either all the same across SWFs in the sample or are non-zero only for one SWF.

${ }^{29}$ Table 6 shows that the coefficient on Credit ratings is negative and statistically significant at 5 percent. This variable takes on positive values in cases which the SWF limits its investments based on credit ratings. Since firms without credit ratings tend to be more opaque, the information effect of SWF investments can be larger for investments made by SWFs that do not have such limitation. That is, the average market reaction is likely larger for SWF investments in more opaque firms. Further, such SWFs are likely to follow more conservative investment strategies and, accordingly generate less in the way of excess returns.

${ }^{30}$ Banks are defined as firms with a code of 45 (banking) in the Fama and French (1997) classification code.

3185 announcements include information about whether the SWF purchase involves new or existing shares of target firms. 53 of them are for existing shares and 32 are for new shares.

${ }^{32}$ Our previously reported cross-sectional results are robust to the inclusion of this variable (untabulated).

${ }^{33}$ In particular, the coefficient on free cash flows, defined as the ratio of earnings after interest and taxes minus capital expenditures to total assets, is $0.048(\mathrm{t}=0.78)$ in equation (1).

${ }^{34}$ Numerous papers show that the ability to identify and terminate poorly performing CEOs is a direct outcome and a necessary component of effective corporate governance (e.g., Hermalin and Weisbach, 2003; Volpin, 2002). While the ownership and board structure can also change over time, such governance mechanisms can substitute for one another, making it difficult to determine if changes in them are indeed in response to SWF activism.

${ }^{35}$ The sample size drops to 29 from 66 when we examine CEO turnover conditional on firm performance because the performance measure is missing for many firms.

${ }^{36} \mathrm{We}$ also test whether the positive market reaction comes at the expense of target firms' creditors or it is due to the market's expectation that SWFs can bail out target firms in case they face financial difficulties in 
the future. If SWF acquisitions lead to a transfer of wealth from creditors to shareholders, highly levered firms should experience higher CARs. We investigate this possibility by checking if the coefficient on leverage is positive and statistically significant in Table 5 . The coefficient estimate is generally negative and never significant, suggesting a wealth distribution effect is not present in our sample. Further, SWFs do not gain a majority of the votes in most acquisitions, and some investments involve new share issuance that reduces leverage. The insignificant coefficient on leverage also implies that the positive market reaction is not due to the market's expectation that SWFs may recapitalize the target firm in case of future financial difficulties, as firms with higher debt ratios are more likely to experience financial distress in the future. 